\title{
A Systematic Review of Epstein-Barr Virus Latent Membrane Protein 1 (LMP1) Gene Variants in Nasopharyngeal Carcinoma
}

\author{
Ana Banko ${ }^{1, *(\mathbb{D})}$, Danijela Miljanovic ${ }^{1}(\mathbb{D})$, Ivana Lazarevic ${ }^{1}(\mathbb{D})$ and Andja Cirkovic ${ }^{2} \mathbb{D}$ \\ 1 Institute of Microbiology and Immunology, Faculty of Medicine, University of Belgrade, \\ 11000 Belgrade, Serbia; danijela.karalic@med.bg.ac.rs (D.M.); ivana.lazarevic@med.bg.ac.rs (I.L.) \\ 2 Institute for Medical Statistics and Informatics, Faculty of Medicine, University of Belgrade, \\ 11000 Belgrade, Serbia; andja.cirkovic@med.bg.ac.rs \\ * Correspondence: ana.banko@med.bg.ac.rs
}

Citation: Banko, A.; Miljanovic, D.; Lazarevic, I.; Cirkovic, A. A Systematic Review of Epstein-Barr Virus Latent Membrane Protein 1 (LMP1) Gene Variants in Nasopharyngeal Carcinoma. Pathogens 2021, 10, 1057. https:// doi.org/10.3390/pathogens10081057

Academic Editor: Chi Man Tsang

Received: 30 June 2021

Accepted: 26 July 2021

Published: 20 August 2021

Publisher's Note: MDPI stays neutral with regard to jurisdictional claims in published maps and institutional affiliations.

Copyright: (c) 2021 by the authors. Licensee MDPI, Basel, Switzerland. This article is an open access article distributed under the terms and conditions of the Creative Commons Attribution (CC BY) license (https:// creativecommons.org/licenses/by/ $4.0 /)$.

\begin{abstract}
Nasopharyngeal carcinoma (NPC) is an aggressive tumor with a complex etiology. Although Epstein-Barr virus (EBV) infection is known environmental factor for NPC development, the degree to which EBV naturally infects nasopharyngeal epithelium and the moment when and why the virus actively begins to affect cell transformation remains questionable. The aim of this study was to explore the association between LMP1 gene variability and potential contribution to NPC development. A systematic review was performed through searches of PubMed, Web of Science (WoS) and SCOPUS electronic databases. Additionally, meta-analysis of the difference in the frequency of seven LMP1 gene variants in NPC and control individuals was accomplished. The results from this study give a proof of concept for the association between $30 \mathrm{bp}$ deletion $(\mathrm{OR}=3.53$, 95\% CI $=1.48-8.43)$ and Xhol loss (OR $=14.17,95 \% \mathrm{CI}=4.99-40.20)$ and NPC susceptibility when comparing biopsies from NPC and healthy individuals. Otherwise, $30 \mathrm{bp}$ deletion from NPC biopsies could not distinguish NPC from EBV-associated non-NPC tumors (OR $=1.74,95 \% \mathrm{CI}=0.81-3.75)$. However, B95-8, China1 and North Carolina variants were uncommon for NPC individuals. Much more efforts remains to be done to verify the biological significance of the differences observed, define so-called "high-risk" EBV variants and make it available for clinical application.
\end{abstract}

Keywords: EBV; nasopharyngeal carcinoma; LMP1; gene variability; variants; meta-analysis

\section{Introduction}

Nasopharyngeal carcinoma (NPC) is a rare but aggressive tumor that originates from the epithelial cells of the retronasal cavity. Although it could be presented with varying degrees of differentiation, the undifferentiated carcinoma of nasopharyngeal type (UCNT, World Health Organization type III) is the most dominant histopathological type in highrisk areas. Unlike most of the world's population, including Europe and USA where NPC is rare with an incidence below 1 per 100,000 persons per year, in endemic regions of Asia incidence rate is $20-30$ per 100,000 persons per year [1]. According to data from $2020,85.2 \%$ of newly registered cases globally belong to the Asian continent [2]. Striking geographic distribution of NPC is the result of the complex etiology of this carcinoma. It has been suggested that both genetic and environmental factors could play a role in the development of NPC. Genetic predisposition is based on HLA (human leukocyte antigen) polymorphisms and chromosomal $3 \mathrm{p} \mathrm{LOH} \mathrm{(loss} \mathrm{of} \mathrm{heterozygosity),} \mathrm{which} \mathrm{is} \mathrm{supported} \mathrm{by}$ finding of NPC clustering in families from diverse populations [3,4]. On the other hand, environmental factors include food common to Southern Chinese cultures, in particular consumption of salted fish, tobacco smoke, alcohol consumption, inhalant and Epstein-Barr virus (EBV) infection $[3,5]$.

The association of NPC and EBV was first discovered by seroepidemiological studies which revealed elevated anti-EBV IgA antibodies in patients with NPC [6,7]. In addition, the level of antibody titers was higher in UCNT patients in comparison to squamous 
cell carcinoma (SCCs) patients. Additionally, EBV-encoded small RNAs (EBERs), which are expressed in all patterns of EBV latent infection, were detected in UCNTs but not in SCCs [8]. As a key environmental factor of UCNT, EBV infection has been identified as a group 1 carcinogenic agent by the International Agency for Research and Cancer (IARC). EBV latently infects NPC cells and occasionally enters productive lytic infection. However, the degree to which EBV naturally infects nasopharyngeal epithelium and the moment when the virus is acquired by the NPC progenitor population during tumor development remains questionable. The establishment of latent transforming infection based on limited viral protein expression includes activity of latent membrane protein 1 (LMP1), a crucial viral oncogene. It has been shown that LMP1 transforms rodent fibroblast in vitro and induces tumors in nude mice $[9,10]$. The oncogenic potential of LMP1 is suggested by its high functional similarity to the tumor necrosis factor (TNFR) receptor family members, CD40 and TNFR1 [11]. The effect that LMP1 exerts during NPC pathogenesis includes upregulation of the anti-apoptotic $A 20$ and $b c l-2$ genes, a modulation of the morphology and motility of epithelial cells, a downregulation of metastasis suppressors, promotion of angiogenesis and activation of proinflammatory cytokines [12]. It has been proven that the aggressiveness manifested in metastasis-prone behavior of EBV-positive NPC is particularly associated with the expression of the LMP1 [13].

LMP1 is a 356 amino acid integral membrane protein formed by three domains: a short N-terminal tail (amino acids 1-23); six transmembrane domains (amino acids 24-186); the long cytoplasmic C-terminal tail (amino acids 187-386) with three distinct functional domains or the C-terminal activation regions (CTAR) 1, 2, and 3 [14,15]. Investigation of LMP1 gene variability is particularly interesting since it is significantly heterogeneous with a greater degree of polymorphism than most of the other EBV genes [16]. Seven main LMP1 strains have been defined based on nucleotide sequence variations relative to the wildtype strain B95-8: Alaskan (AL), China1, China2, China3, Mediterranean with (Med+) or without (Med-) deletions, and North Carolina (NC) [17,18]. However, several new strains have been reported in the years following the establishment of the basic classification [19]. It is important to note that LMP1 variants with the $30 \mathrm{bp}$ deletion (30 bp del) correlated with higher transforming ability and lower immunogenic potential of EBV [20]. The similar properties are described in $69 \mathrm{bp}$ deletion ( $69 \mathrm{bp} \mathrm{del}$ ) and in the loss of a restriction site in the N-terminal tail, known as XhoI [12,19].

Understanding EBV molecular epidemiology could be crucial in preventing and treating all pathological conditions associated with viral infection. Considering the heterogeneity of the examined populations in previous studies, there are the ambiguous results and the lack of definitive conclusions about the association between LMP1 gene variability and potential contribution to NPC development. The aim of this systematic review and meta-analysis was to explore this problem.

\section{Results}

\subsection{Systematic Review}

A total of 3420 potentially eligible articles were found. After duplicates $(n=1619)$ removed, title and abstracts were evaluated for 1801 articles. In total, 1747 articles were excluded because they were not original articles, did not explore NPCs, did not compare NPC and control groups, examined populations other than human (animals, cell lines), explored genes other than LMP1, explored the presence of LMP1 and/or its expression level but not LMP1 variants, or were abstracts. Of the 54 reviewed full text articles, 31 were selected for inclusion in the systematic review. A flow diagram illustrating this selection process is presented in Figure 1. 


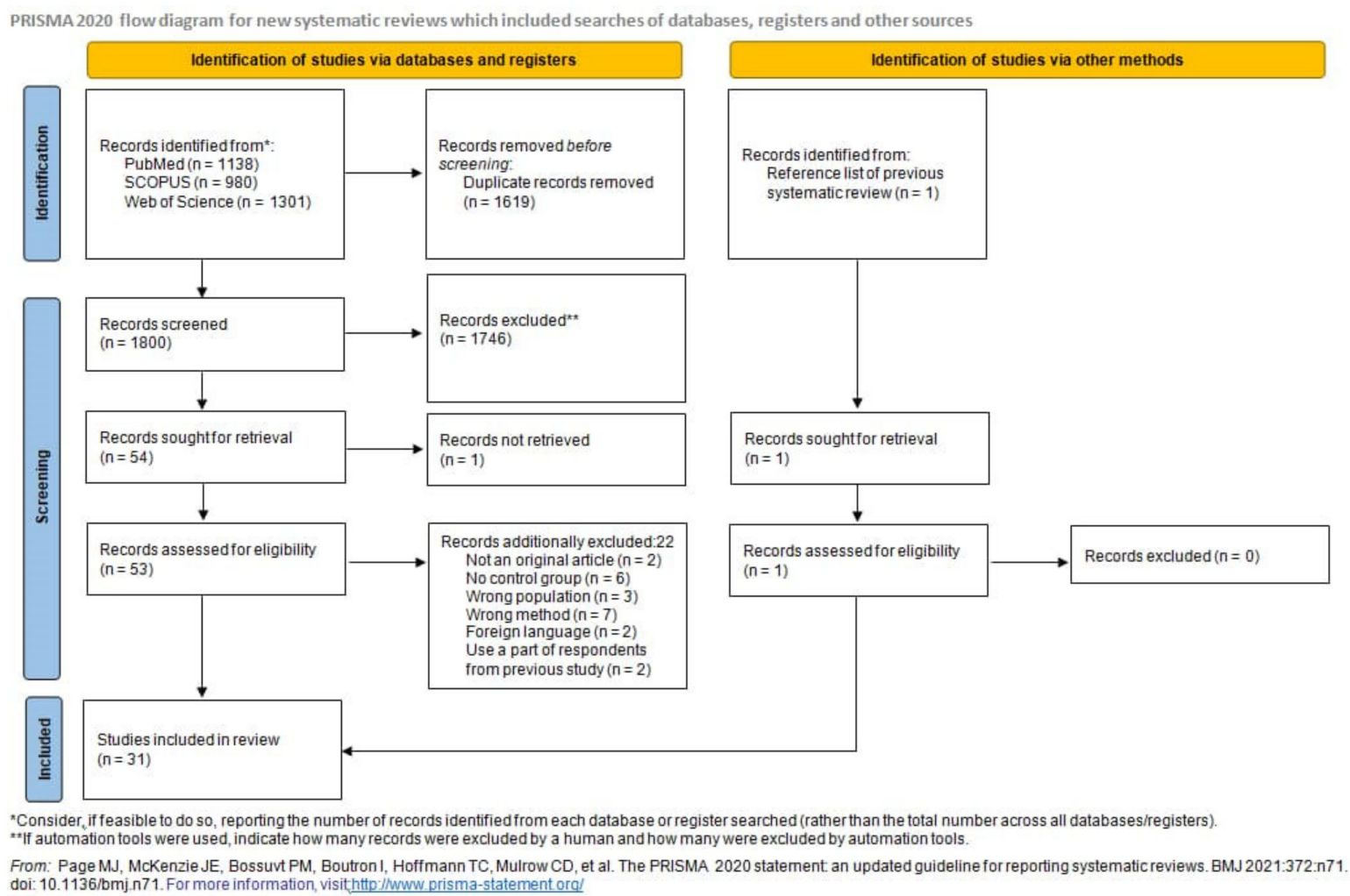

Figure 1. Flow chart.

Characteristics of all 31 publications included in the systematic review are presented in detail in Table 1. They were published between 1992 and 2019, with a total of 3371 participants: 1705 patients with and 1666 without NPC. The number of EBV positive NPC patients was 1595, and there were $1330 \mathrm{EBV}$ positive controls. The minimum sample size of the NPC group was one, and of the control group was three. The maximum size of the NPC group was 154, and the control group was 269. Only 3 studies reported their design ( 2 case-controls and 1 cross-sectional study). Most studies were from China (9). Six were multicenter studies, while one did not report the country of origin. Other studies were done in Taiwan (2), Russia (3), Spain (1), Malaysia (2), Argentina (1), Morocco (1), Tunis (1), Thailand (1), Serbia (1), Portugal (1), and Iran (1). The majority of all studies $(15 / 31)$ originated from endemic regions for NPCs. Five out of six multicenter studies were from endemic and non-endemic regions. Five were from non-endemic regions only.

Biopsy epithelial tissue of NPC patients was commonly evaluated (28/31 studies). Other sources for EBV LMP1 variants detection from NPC patients were peripheral blood in 8 studies (whole blood in 3, peripheral blood mononuclear cells in 1, peripheral blood lymphocytes in 1, peripheral blood leukocytes in 1, serum in 1, and plasma in 1 study), throat washing in 5 , and xenografts in 1 study. Control groups were very heterogeneous. Most common sources of a control sample were patients with lymphomas, then nonNPC tumors, infectious mononucleosis, nasopharyngeal inflammation, and oral hairy leukoplakia. Three ways of sampling were implemented: biopsy, blood sampling and throat washing.

The age of the participants ranged from 2 to 86 years; however, the predominant age was approximately 50 years. In the NPC group age ranged from 2 to 86 years and in the control group from 5 to 77 years. Regarding the gender of the participants, there was a male predominance with a male/female ratio of 1.87 (in NPC group male/female ratio was 2.5 and in the control group it was 1.2).

Summary of findings from this study is presented in the Supplementary Table (Table S1). 
Table 1. Characteristics of studies included in the systematic review.

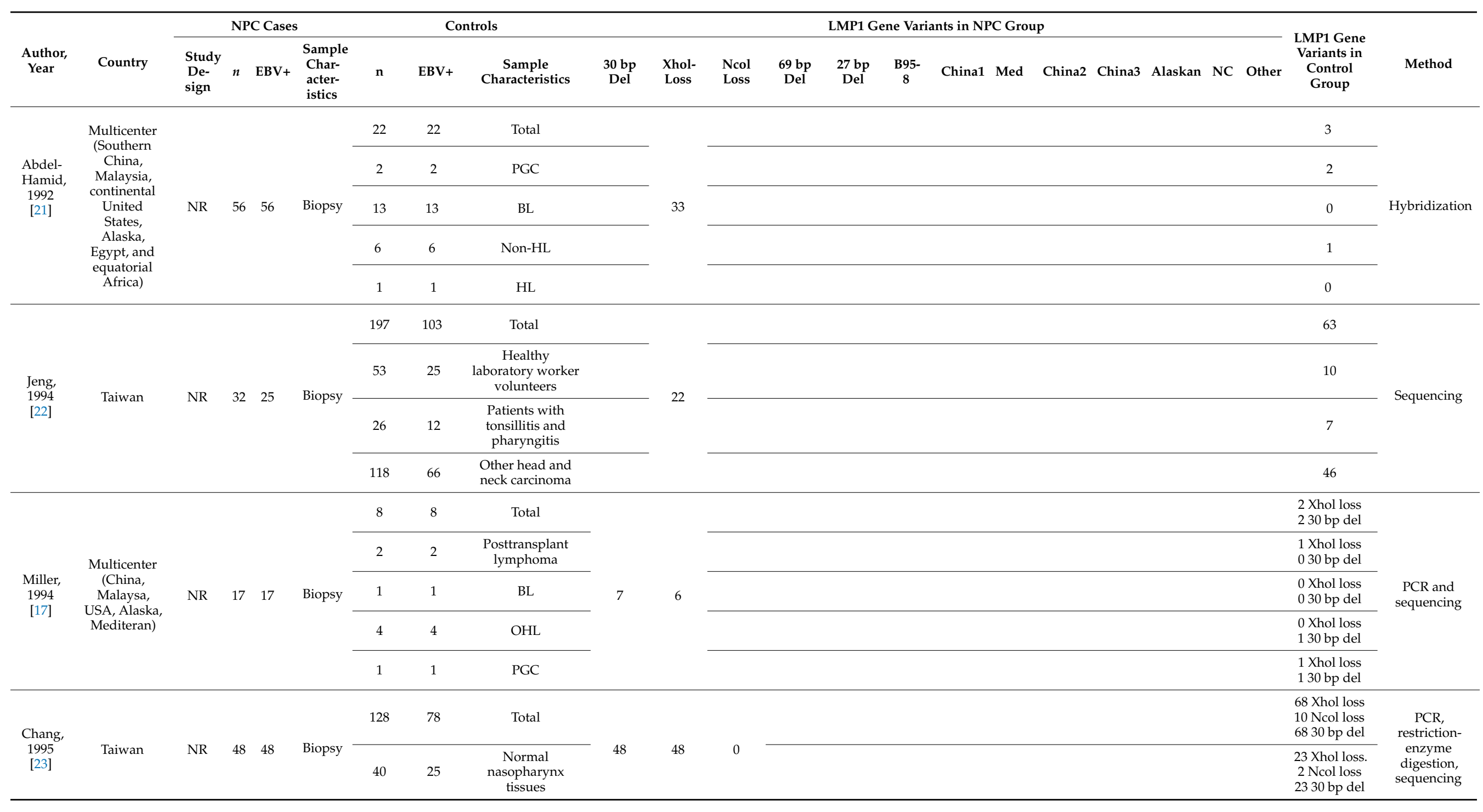


Table 1. Cont.

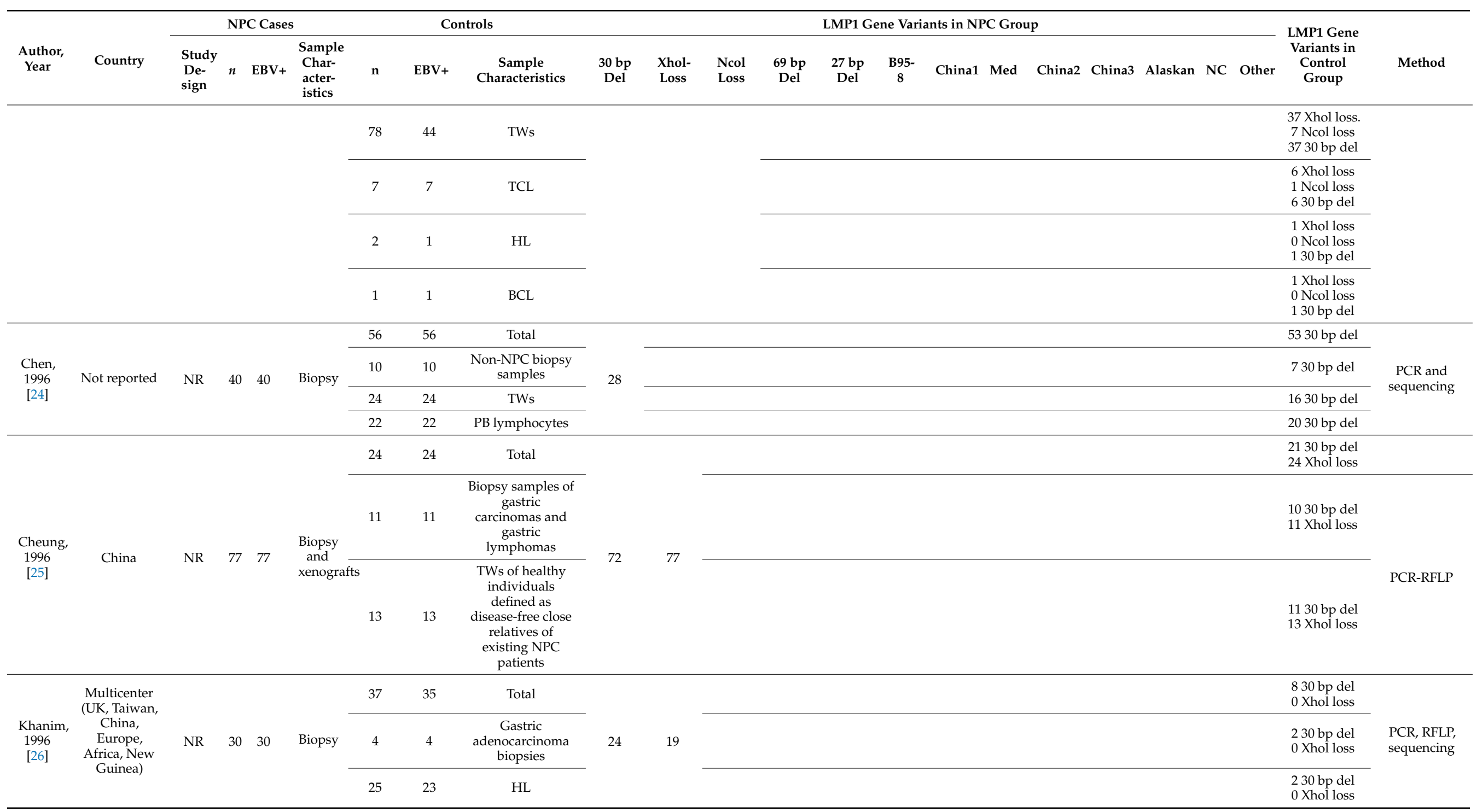


Table 1. Cont.

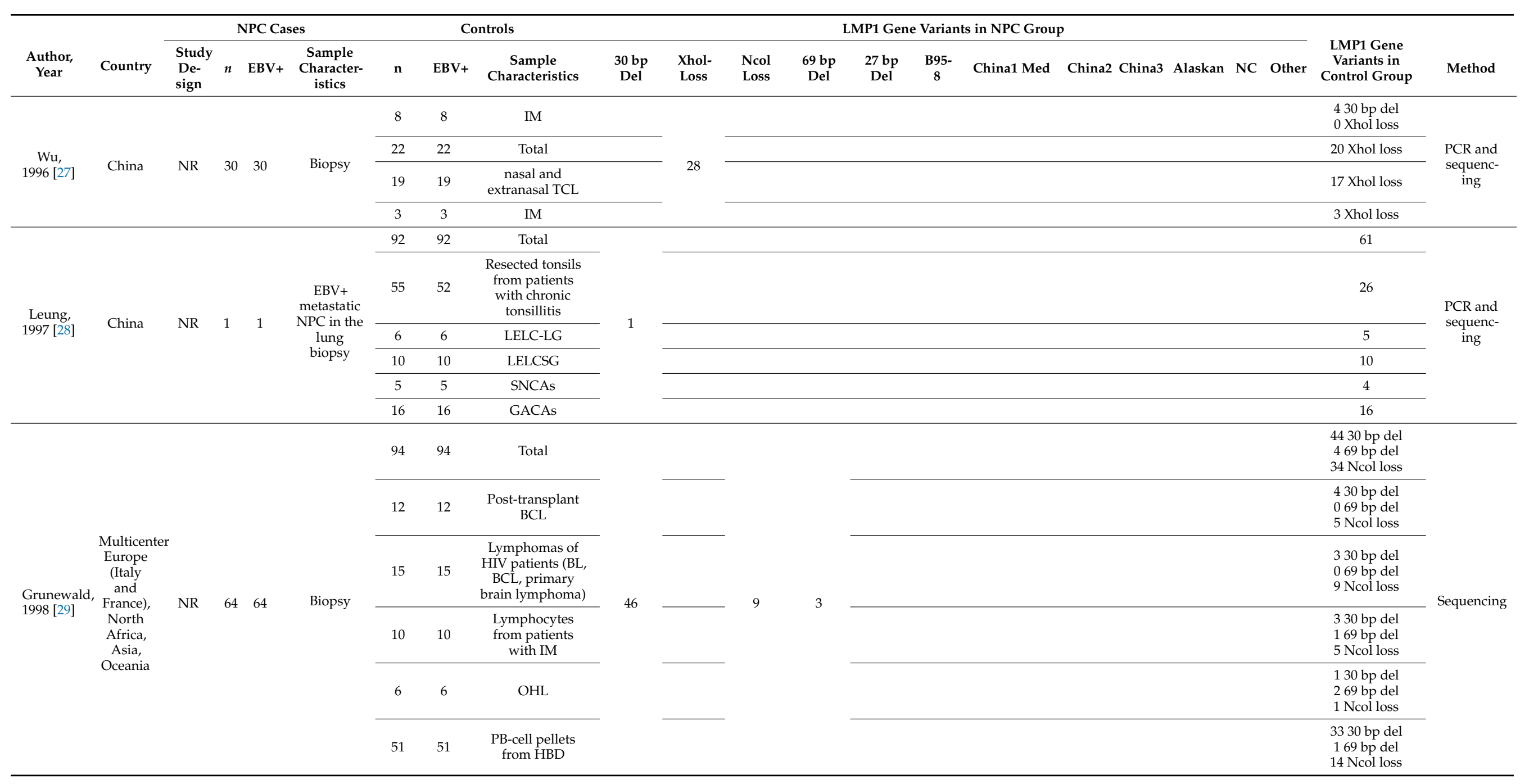


Table 1. Cont.

\begin{tabular}{|c|c|c|c|c|c|c|c|c|c|c|c|c|c|c|c|c|c|c|c|c|c|c|}
\hline \multirow[b]{2}{*}{$\begin{array}{l}\text { Author, } \\
\text { Year }\end{array}$} & \multirow[b]{2}{*}{ Country } & \multicolumn{4}{|c|}{ NPC Cases } & \multicolumn{3}{|c|}{ Controls } & \multicolumn{12}{|c|}{ LMP1 Gene Variants in NPC Group } & \multirow{2}{*}{$\begin{array}{l}\text { LMP1 Gene } \\
\text { Variants in } \\
\text { Control } \\
\text { Group }\end{array}$} & \multirow[b]{2}{*}{ Method } \\
\hline & & $\begin{array}{l}\text { Study } \\
\text { De- } \\
\text { sign }\end{array}$ & $n$ & EBV+ & $\begin{array}{l}\text { Sample } \\
\text { Char- } \\
\text { acter- } \\
\text { istics }\end{array}$ & $\mathbf{n}$ & EBV+ & $\begin{array}{l}\text { Sample } \\
\text { Characteris- } \\
\text { tics }\end{array}$ & $\begin{array}{c}30 \mathrm{bp} \\
\text { Del }\end{array}$ & $\begin{array}{l}\text { Xhol- } \\
\text { Loss }\end{array}$ & $\begin{array}{l}\text { Ncol } \\
\text { Loss }\end{array}$ & $\begin{array}{c}69 \mathrm{bp} \\
\mathrm{Del}\end{array}$ & $\begin{array}{c}27 \mathrm{bp} \\
\text { Del }\end{array}$ & $\begin{array}{l}\text { B95- } \\
8\end{array}$ & China1 & Med & China2 & China3 & Alaskan & NC Other & & \\
\hline $\begin{array}{l}\text { Hahn, } \\
2001 \\
{[30]}\end{array}$ & Russia & NR & 7 & 7 & Biopsy & 11 & 11 & $\begin{array}{l}\text { NPC-like } \\
\text { tumor of the } \\
\text { parotid } \\
\text { gland, } \\
\text { healthy } \\
\text { carriers' PB } \\
\text { lymphocytes }\end{array}$ & 0 & & & & & & & & & & & & 3 & Sequencing \\
\hline \multirow{3}{*}{$\begin{array}{l}\text { Zhou, } \\
2001 \\
{[31]}\end{array}$} & \multirow{3}{*}{ China } & \multirow{3}{*}{ NR } & \multirow{3}{*}{6} & \multirow{3}{*}{6} & \multirow{3}{*}{ Biopsy } & 94 & $\begin{array}{c}30 \\
\text { sequenced }\end{array}$ & Total & \multirow{3}{*}{2} & \multirow{3}{*}{5} & & & & & & & & & & & $\begin{array}{l}1030 \text { bp del } \\
11 \text { Xhol loss }\end{array}$ & \multirow{3}{*}{ Sekvencing } \\
\hline & & & & & & 21 & $\begin{array}{c}21(2 \mathrm{~N} \\
\text { terminus }+ \\
2 \mathrm{C} \\
\text { terminus } \\
\text { for se- } \\
\text { quencing) }\end{array}$ & $\begin{array}{l}\text { TWs from } \\
\text { healthy } \\
\text { Chinese }\end{array}$ & & & & & & & & & & & & & $\begin{array}{c}130 \text { bp del } 1 \\
\text { Xhol loss }\end{array}$ & \\
\hline & & & & & & 2 & $\begin{array}{c}2 \text { (only } 2 \mathrm{C} \\
\text { terminus } \\
\text { sequenc- } \\
\text { ing) }\end{array}$ & $\begin{array}{l}\text { Chinese } \\
\text { nasal TNKLs }\end{array}$ & & & & & & & & & & & & & $\begin{array}{c}130 \mathrm{bp} \text { del } 0 \\
\text { Xhol loss }\end{array}$ & \\
\hline
\end{tabular}


Table 1. Cont

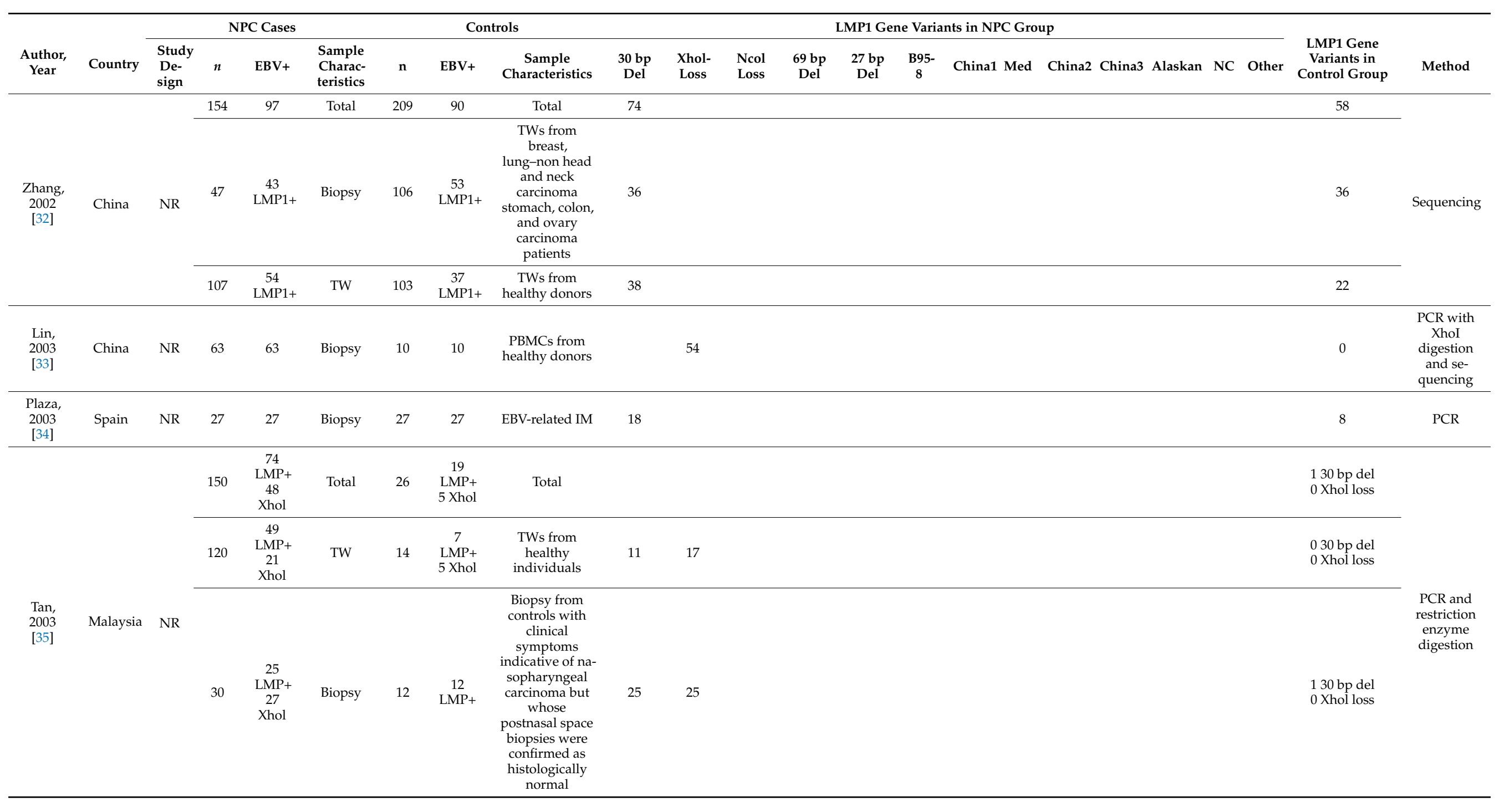


Table 1. Cont.

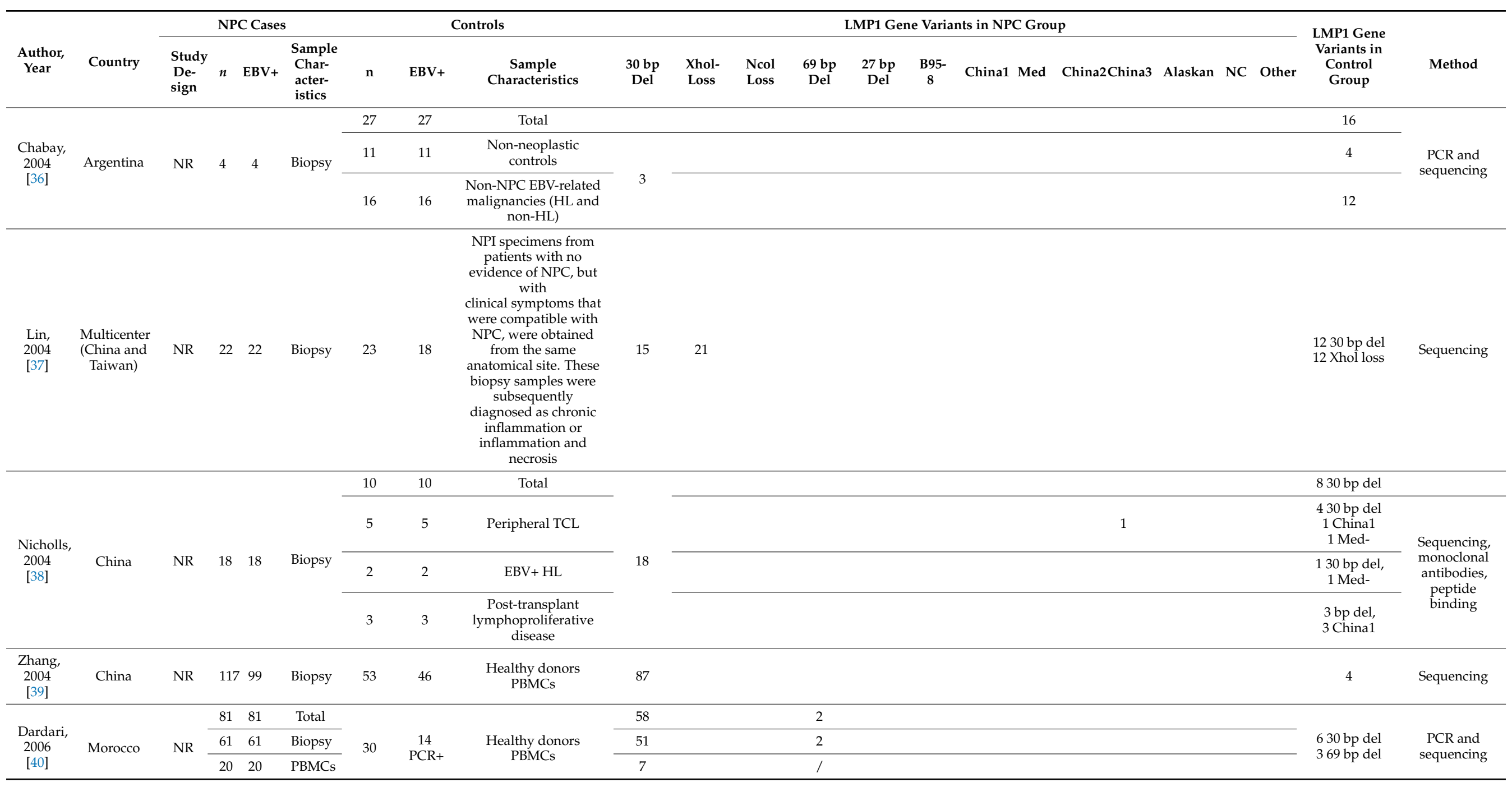


Table 1. Cont.

\begin{tabular}{|c|c|c|c|c|c|c|c|c|c|c|c|c|c|c|c|c|c|c|c|c|c|c|c|}
\hline \multirow[b]{2}{*}{$\begin{array}{l}\text { Author, } \\
\text { Year }\end{array}$} & \multirow[b]{2}{*}{ Country } & \multicolumn{4}{|c|}{ NPC Cases } & \multicolumn{3}{|c|}{ Controls } & \multicolumn{13}{|c|}{ LMP1 Gene Variants in NPC Group } & \multirow{2}{*}{$\begin{array}{l}\text { LMP1 Gene } \\
\text { Variants in } \\
\text { Control } \\
\text { Group }\end{array}$} & \multirow[b]{2}{*}{ Method } \\
\hline & & $\begin{array}{l}\text { Study } \\
\text { De- } \\
\text { sign }\end{array}$ & $n$ & EBV+ & $\begin{array}{l}\text { Sample } \\
\text { Char- } \\
\text { acter- } \\
\text { istics }\end{array}$ & $\mathrm{n}$ & EBV+ & $\begin{array}{c}\text { Sample } \\
\text { Characteristics }\end{array}$ & $\begin{array}{c}30 \mathrm{bp} \\
\text { Del }\end{array}$ & $\begin{array}{l}\text { Xhol- } \\
\text { Loss }\end{array}$ & $\begin{array}{l}\text { Ncol } \\
\text { Loss }\end{array}$ & $\begin{array}{l}69 \mathrm{bp} \\
\text { Del }\end{array}$ & $\begin{array}{c}27 \text { bp } \\
\text { Del }\end{array}$ & $\begin{array}{l}\text { B95- } \\
8\end{array}$ & China & Med & China2 & China3 & Alaskan & NC & Other & & \\
\hline \multirow{3}{*}{$\begin{array}{l}\text { Hadhri- } \\
\text { Guiga, } \\
2006 \\
{[41]}\end{array}$} & \multirow{3}{*}{ Tunis } & \multirow{3}{*}{ NR } & 74 & 74 & Total & \multirow{3}{*}{20} & \multirow{3}{*}{17} & \multirow{3}{*}{$\begin{array}{l}\text { Control patients } \\
\text { with clinical } \\
\text { symptoms } \\
\text { indicative of NPC } \\
\text { but whose } \\
\text { postnasal biopsies } \\
\text { were confirmed } \\
\text { as histologically } \\
\text { normal }\end{array}$} & 43 & & & 2 & & & & & & & & & & \multirow{3}{*}{$\begin{array}{l}930 \mathrm{bp} \text { del } \\
069 \mathrm{bp} \text { del }\end{array}$} & \multirow{3}{*}{$\begin{array}{l}\text { Xhol } \\
\text { digestion } \\
\text { and } \\
\text { sequencing }\end{array}$} \\
\hline & & & 42 & 42 & Biopsy & & & & 28 & & & 2 & & & & & & & & & & & \\
\hline & & & 32 & 32 & $\begin{array}{l}\mathrm{PB} \\
\text { lym- } \\
\text { pho- } \\
\text { cytes }\end{array}$ & & & & 15 & & & 0 & & & & & & & & & & & \\
\hline \multirow{3}{*}{$\begin{array}{l}\text { See, } \\
2008 \\
{[42]}\end{array}$} & \multirow{3}{*}{ Malaysia } & \multirow{3}{*}{ NR } & 77 & 77 & Total & \multirow{3}{*}{10} & \multirow{3}{*}{8} & \multirow{3}{*}{$\begin{array}{c}\text { Non-malignant } \\
\text { nasopharyngeal } \\
\text { tissue samples }\end{array}$} & 26 & 45 & & & & & & & & & & & & \multirow{3}{*}{$\begin{array}{l}030 \mathrm{bp} \text { del } \\
0 \text { Xhol loss }\end{array}$} & \multirow{3}{*}{$\begin{array}{c}\text { Xhol } \\
\text { digestion } \\
\text { and } \\
\text { sequencing }\end{array}$} \\
\hline & & & 42 & 42 & Biopsy & & & & 19 & 34 & & & & & & & & & & & & & \\
\hline & & & 35 & 35 & Plasma & & & & 7 & 11 & & & & & & & & & & & & & \\
\hline \multirow{3}{*}{$\begin{array}{l}\text { Tiwawech, } \\
2008 \\
{[43]}\end{array}$} & \multirow{3}{*}{ Thailand } & \multirow{3}{*}{$\begin{array}{l}\text { Case- } \\
\text { control }\end{array}$} & \multirow{3}{*}{75} & \multirow{3}{*}{75} & \multirow{3}{*}{$\begin{array}{l}\text { PB } \\
\text { leuko- } \\
\text { cytes }\end{array}$} & 44 & 44 & Total & \multirow{3}{*}{44} & & & & & & & & & & & & & & \\
\hline & & & & & & 20 & 20 & $\begin{array}{c}\text { Randomly } \\
\text { recruited } \\
\text { age-matched } \\
\text { (mean age } \pm \\
5 \text { years) healthy } \\
\text { subjects } \\
\end{array}$ & & & & & & 0 & 20 & 0 & 6 & 0 & 0 & 0 & 4 & 16 & $\begin{array}{l}\text { PCR and } \\
\text { sequencing }\end{array}$ \\
\hline & & & & & & 24 & 24 & $\begin{array}{c}\text { Non-NPC } \\
\text { patients } \\
\text { with cancer and } \\
\text { other disease }\end{array}$ & & & & & & & & & & & & & & & \\
\hline & & & 150 & 150 & Total & 269 & 253 & Total & 74 & & & & & 1 & 131 & 3 & 11 & 0 & 0 & 0 & 3 & $\begin{array}{l}8730 \mathrm{bp} \text { del } \\
91 \text { China1 } \\
5 \text { China2 } \\
30 \text { B95-8 } \\
1 \text { Med } \\
12 \text { other } \\
\text { strains }\end{array}$ & \\
\hline $\begin{array}{c}\mathrm{Li}, \\
2009 \\
{[44]}\end{array}$ & China & NR & 50 & 50 & Biopsy & 15 & 9 & $\begin{array}{l}\text { Biopsy from } \\
\text { patients with } \\
\text { nasopharyngeal } \\
\text { chronic } \\
\text { inflammation }\end{array}$ & 39 & & & & & 0 & 94 & 2 & 5 & 0 & 0 & 0 & 0 & $\begin{array}{l}830 \text { bp del } \\
14 \text { China1 } \\
1 \text { China } 2\end{array}$ & $\begin{array}{l}\text { PCR and } \\
\text { sequencing }\end{array}$ \\
\hline & & & 50 & 50 & TW & 9 & 9 & $\begin{array}{c}\text { TW from } \\
\text { patients with } \\
\text { nasopharyngeal } \\
\text { chronic } \\
\text { inflammation }\end{array}$ & 30 & & & & & 1 & 37 & 1 & 6 & 0 & 0 & 0 & 3 & $\begin{array}{l}630 \mathrm{bp} \text { del } \\
8 \text { China1 }\end{array}$ & \\
\hline
\end{tabular}


Table 1. Cont.

\begin{tabular}{|c|c|c|c|c|c|c|c|c|c|c|c|c|c|c|c|c|c|c|c|c|c|c|}
\hline \multirow[b]{2}{*}{$\begin{array}{l}\text { Author, } \\
\text { Year }\end{array}$} & \multirow[b]{2}{*}{ Country } & \multicolumn{4}{|c|}{ NPC Cases } & \multicolumn{3}{|c|}{ Controls } & \multicolumn{12}{|c|}{ LMP1 Gene Variants in NPC Group } & \multirow[b]{2}{*}{$\begin{array}{l}\text { LMP1 Gene } \\
\text { Variants in } \\
\text { Control Group }\end{array}$} & \multirow[b]{2}{*}{ Method } \\
\hline & & $\begin{array}{l}\text { Study } \\
\text { De- } \\
\text { sign }\end{array}$ & $n$ & EBV+ & $\begin{array}{l}\text { Sample } \\
\text { Char- } \\
\text { acter- } \\
\text { istics } \\
\end{array}$ & n & EBV+ & $\begin{array}{c}\text { Sample } \\
\text { Characteristics }\end{array}$ & $\begin{array}{c}30 \mathrm{bp} \\
\text { Del }\end{array}$ & $\begin{array}{l}\text { Xhol- } \\
\text { Loss }\end{array}$ & $\begin{array}{l}\text { Ncol } \\
\text { Loss }\end{array}$ & $\begin{array}{c}69 \mathrm{bp} \\
\text { Del }\end{array}$ & $\begin{array}{c}27 \mathrm{bp} \\
\text { Del }\end{array}$ & $\begin{array}{c}\text { B95- } \\
8\end{array}$ & China1 & Med & China2 & China3 & Alaskan & NC Other & & \\
\hline & & & & & & 55 & 55 & $\begin{array}{c}\text { TW from } \\
\text { patients with } \\
\text { other cancers }\end{array}$ & & & & & & & & & & & & & $\begin{array}{c}030 \text { bp del } \\
30 \text { China1 } \\
20 \text { B95-8 } \\
2 \text { China2 } \\
1 \text { Med } \\
6 \text { other strains }\end{array}$ & \\
\hline & & & & & & 63 & 63 & $\begin{array}{l}\text { Biopsy samples } \\
\text { from } \\
\text { patients with } \\
\text { other cancers }\end{array}$ & & & & & & & & & & & & & 4030 bp del & \\
\hline & & & & & & 59 & 52 & $\begin{array}{c}\text { TW from } \\
\text { healthy } \\
\text { Cantonese donors }\end{array}$ & & & & & & & & & & & & & $\begin{array}{c}3330 \text { bp del } \\
39 \text { China1 } \\
10 \text { B95-8 } \\
2 \text { China2 } 2 \\
6 \text { other strains }\end{array}$ & \\
\hline & & & & & & 59 & 56 & $\begin{array}{c}\text { PB from } \\
\text { healthy } \\
\text { Cantonese donors }\end{array}$ & & & & & & & & & & & & & $030 \mathrm{bp}$ del & \\
\hline \multirow{3}{*}{$\begin{array}{l}\text { Banko, } \\
2012 \\
{[45]}\end{array}$} & \multirow{3}{*}{ Serbia } & \multirow{3}{*}{ NR } & \multirow{3}{*}{16} & \multirow{3}{*}{16} & \multirow{3}{*}{ Biopsy } & 37 & 37 & Total & \multirow{3}{*}{1} & & & \multirow{3}{*}{3} & \multirow{3}{*}{0} & \multirow{3}{*}{5} & \multirow{3}{*}{1} & \multirow{3}{*}{6} & \multirow{3}{*}{0} & \multirow{3}{*}{0} & \multirow{3}{*}{0} & & $\begin{array}{c}1230 \mathrm{bp} \text { del } \\
169 \mathrm{bp} \text { del } \\
127 \mathrm{bp} \text { del } \\
12 \mathrm{~B} 95-8 \\
12 \text { China1 } \\
7 \text { Med }\end{array}$ & \multirow{3}{*}{ Sequencing } \\
\hline & & & & & & 30 & 30 & $\begin{array}{l}\text { Plasma samples } \\
\text { from patients } \\
\text { with } \\
\text { mononucleosis } \\
\text { syndrome }\end{array}$ & & & & & & & & & & & & 4 & $\begin{array}{c}1030 \mathrm{bp} \text { del } \\
069 \mathrm{bp} \text { del } \\
127 \mathrm{bp} \text { del } \\
10 \text { B95-8 } \\
10 \text { China1 } \\
6 \mathrm{NC} \\
4 \mathrm{Med}\end{array}$ & \\
\hline & & & & & & 6 & 6 & $\begin{array}{c}\text { Plasma samples } \\
\text { after } \\
\text { renal } \\
\text { transplantation }\end{array}$ & & & & & & & & & & & & & $\begin{array}{c}230 \mathrm{bp} \text { del } \\
169 \mathrm{bp} \text { del } \\
027 \mathrm{bp} \text { del } \\
2 \text { B95-8 } \\
2 \text { China } \\
2 \text { Med }\end{array}$ & \\
\hline
\end{tabular}


Table 1. Cont

\begin{tabular}{|c|c|c|c|c|c|c|c|c|c|c|c|c|c|c|c|c|c|c|c|c|c|c|c|}
\hline \multirow[b]{2}{*}{$\begin{array}{l}\text { Author, } \\
\text { Year }\end{array}$} & \multirow[b]{2}{*}{ Country } & \multicolumn{4}{|c|}{ NPC Cases } & \multicolumn{3}{|c|}{ Controls } & \multicolumn{13}{|c|}{ LMP1 Gene Variants in NPC Group } & \multirow[b]{2}{*}{$\begin{array}{l}\text { LMP1 Gene } \\
\text { Variants in } \\
\text { Control Group }\end{array}$} & \multirow[b]{2}{*}{ Method } \\
\hline & & $\begin{array}{l}\text { Study } \\
\text { De- } \\
\text { sign }\end{array}$ & $n$ & EBV+ & $\begin{array}{l}\text { Sample } \\
\text { Char- } \\
\text { acter- } \\
\text { istics }\end{array}$ & $\mathrm{n}$ & EBV+ & $\begin{array}{c}\text { Sample } \\
\text { Characteristics }\end{array}$ & $\begin{array}{c}30 \mathrm{bp} \\
\text { Del }\end{array}$ & $\begin{array}{l}\text { Xhol- } \\
\text { Loss }\end{array}$ & $\begin{array}{l}\text { Ncol } \\
\text { Loss }\end{array}$ & $\begin{array}{l}69 \mathrm{bp} \\
\text { Del }\end{array}$ & $\begin{array}{c}27 \mathrm{bp} \\
\text { Del }\end{array}$ & $\begin{array}{l}\text { B95- } \\
8\end{array}$ & China1 & Med & China2 & China3 & Alaskan & NC & Other & & \\
\hline \multirow{4}{*}{$\begin{array}{l}\text { Gurtsevitch, } \\
2013 \text { [46] }\end{array}$} & \multirow{4}{*}{ Russia } & \multirow{4}{*}{ NR } & 57 & 57 & Total & 69 & 55 & Total & 5 & & & 12 & & 16 & 2 & 29 & 0 & 0 & 0 & 6 & 4 & $\begin{array}{c}1930 \mathrm{bp} \text { del } \\
169 \mathrm{bp} \text { del } \\
21 \mathrm{Bg5-8} \\
16 \mathrm{China} 1 \\
5 \mathrm{Med}+ \\
6 \mathrm{Med}- \\
6 \mathrm{NC} \\
0 \text { other }\end{array}$ & \multirow{4}{*}{ Sequencing } \\
\hline & & & 21 & 21 & Biopsy & 20 & 14 & $\begin{array}{c}\text { OTOC } \\
\text { (patients with } \\
\text { cancer } \\
\text { of the oral } \\
\text { mucosa, tongue, } \\
\text { sublingual tonsil, } \\
\text { and some other } \\
\text { malignant } \\
\text { affections of the } \\
\text { oral cavity) } \\
\text { biopsy }\end{array}$ & 3 & & & 6 & & 6 & 2 & 10 & 0 & 0 & 0 & 1 & 2 & $\begin{array}{c}\text { OTOC biopsy } 7 \\
30 \text { bp del } \\
169 \text { bp del } \\
2 \text { B95-8 } \\
5 \text { China } 1 \\
3 \text { Med+ } \\
2 \text { Med- } \\
2 \text { NC } \\
0 \text { other }\end{array}$ & \\
\hline & & & 16 & 16 & $\mathrm{~PB}$ & 20 & 13 & OTOC blood & 1 & & & 1 & & 4 & 0 & 9 & 0 & 0 & 0 & 2 & 1 & $\begin{array}{l}\text { OTOC blood } 8 \\
30 \text { bp del } 069 \\
\text { bp del } \\
2 \text { B95-8 } \\
7 \text { China1 } \\
1 \text { Med }+ \\
1 \text { Med- } \\
1 \text { NC } \\
0 \text { other }\end{array}$ & \\
\hline & & & & & & 20 & 19 & Blood donors & & & & & & & & & & & & & & $\begin{array}{c}\text { Blood donors } \\
15 \text { B95-8 } \\
1 \text { China } 1 \\
0 \text { Med+ } \\
1 \text { Med- } \\
2 \text { NC } \\
0 \text { other }\end{array}$ & \\
\hline
\end{tabular}


Table 1. Cont.

\begin{tabular}{|c|c|c|c|c|c|c|c|c|c|c|c|c|c|c|c|c|c|c|c|c|c|c|c|}
\hline \multirow[b]{2}{*}{$\begin{array}{l}\text { Author, } \\
\text { Year }\end{array}$} & \multirow[b]{2}{*}{ Country } & \multicolumn{4}{|c|}{ NPC Cases } & \multicolumn{3}{|c|}{ Controls } & \multicolumn{13}{|c|}{ LMP1 Gene Variants in NPC Group } & \multirow[b]{2}{*}{$\begin{array}{l}\text { LMP1 Gene } \\
\text { Variants in } \\
\text { Control Group }\end{array}$} & \multirow[b]{2}{*}{ Method } \\
\hline & & $\begin{array}{l}\text { Study } \\
\text { De- } \\
\text { sign }\end{array}$ & $n$ & EBV+ & $\begin{array}{l}\text { Sample } \\
\text { Char- } \\
\text { acter- } \\
\text { istics }\end{array}$ & $\mathrm{n}$ & EBV+ & $\begin{array}{c}\text { Sample } \\
\text { Characteristics }\end{array}$ & $\begin{array}{c}30 \mathrm{bp} \\
\text { Del }\end{array}$ & $\begin{array}{l}\text { Xhol- } \\
\text { Loss }\end{array}$ & $\begin{array}{l}\text { Ncol } \\
\text { Loss }\end{array}$ & $\begin{array}{c}69 \mathrm{bp} \\
\mathrm{Del}\end{array}$ & $\begin{array}{c}27 \mathrm{bp} \\
\text { Del }\end{array}$ & $\begin{array}{l}\text { B95- } \\
8\end{array}$ & China1 & Med & China2 & China3 & Alaskan & NC & Other & & \\
\hline \multirow{3}{*}{$\begin{array}{l}\text { Senyuta, } \\
2014 \\
{[47]}\end{array}$} & \multirow{3}{*}{ Russia } & \multirow{3}{*}{ NR } & 56 & 56 & Total & 54 & 54 & Total & 6 & & & 12 & & 15 & 2 & 30 & 0 & 0 & 0 & 5 & 4 & $\begin{array}{c}2230 \mathrm{bp} \text { del } \\
169 \mathrm{bp} \text { del } \\
200 \text { B95-8 } \\
17 \text { China1 } \\
7 \text { Med }+ \\
6 \text { Med- } \\
7 \text { NC } \\
0 \text { other }\end{array}$ & \multirow{3}{*}{ Sequencing } \\
\hline & & & 22 & 22 & Biopsy & 14 & 14 & $\begin{array}{c}\text { Biopsy from } \\
\text { patients with } \\
\text { other (non- } \\
\text { nasopharyngeal } \\
\text { carcinoma) } \\
\text { tumors of the oral } \\
\text { cavity - cancers } \\
\text { of the mucous } \\
\text { membrane of the } \\
\text { tongue (3), floor } \\
\text { of the mouth (2), } \\
\text { cheek } \\
\text { (1), retro molar } \\
\text { area (3), lower jaw } \\
\text { (4), and palate (5) }\end{array}$ & 4 & & & 6 & & 6 & 2 & 11 & 0 & 0 & 0 & 1 & 2 & $\begin{array}{c}\text { Other ca biopsy } \\
730 \text { bp del } \\
169 \text { bp del } \\
2 \text { B95-8 } \\
5 \text { China1 } \\
3 \text { Med+ } \\
2 \text { Med- } \\
2 \text { NC } \\
0 \text { other }\end{array}$ & \\
\hline & & & 15 & 15 & $\mathrm{~PB}$ & 12 & 12 & $\begin{array}{c}\text { Non- } \\
\text { nasopharyngeal } \\
\text { carcinoma } \\
\text { blood samples }\end{array}$ & 1 & & & 1 & & 3 & 0 & 9 & 0 & 0 & 0 & 2 & 1 & $\begin{array}{c}\text { Blood } \\
\text { other ca } \\
930 \mathrm{bp} \text { del } \\
069 \mathrm{bp} \text { del } \\
1 \text { B95-8 } \\
8 \text { China1 } \\
1 \text { Med+ } \\
1 \text { Med- } \\
1 \text { NC } \\
0 \text { other }\end{array}$ & \\
\hline
\end{tabular}


Table 1. Cont.

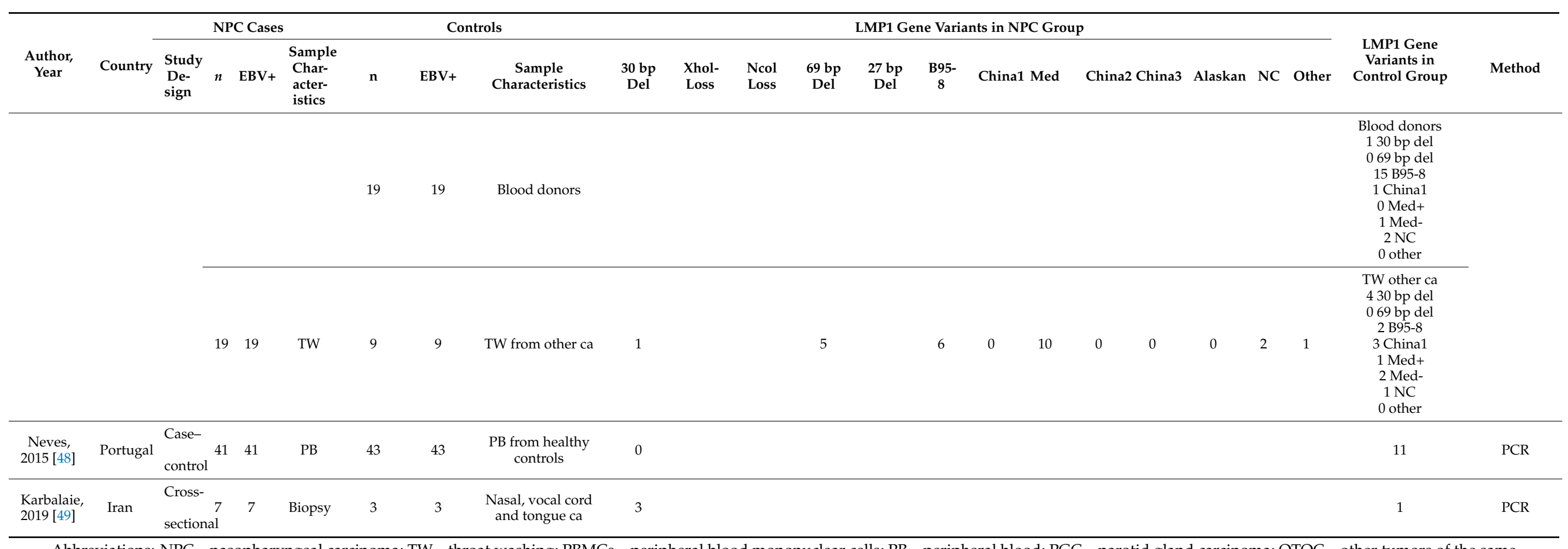

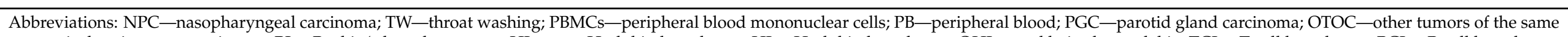

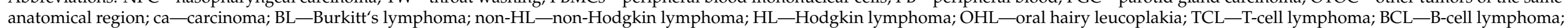

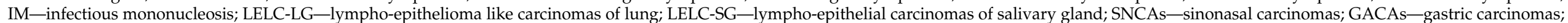
HBD—healthy blood donors; TNKLs—T/natural killer cell lymphoma; NPI—non-neoplastic counterparts. 


\subsection{Meta-Analysis of the Association between LMP1 Variants with NPC}

Meta-analysis was performed for 7 variants (Xhol loss, 30 bp deletion, 69 bp deletion, B95-8, China1, Mediterranean and North Carolina). First, it was accomplished regardless of the country of patient origin, and then by regions (endemic and non-endemic). Only studies that evaluated and compared the frequency of LMP1 gene variants in human NPC and control groups were taken into account.

\subsubsection{Xhol Loss}

A total of 13 studies were included in the meta-analysis of the association between Xhol loss LMP1 variant and NPC susceptibility. Xhol loss showed strong association with NPC susceptibility between NPC and other EBV-associated tumors biopsies (OR $=6.19$, $95 \% \mathrm{CI}=3.55-10.78, p<0.001$ ) (Figure 2), and even stronger association between NPC and healthy respondents' biopsies ( $\mathrm{OR}=14.17,95 \% \mathrm{CI}=4.99-40.20, p<0.001)$ (Figure 3 ). The presence of Xhol loss enlarged the chance for NPC for 6 times in comparison with other tumors, and 14 times in comparison with healthy tissue. The strongest association of Xhol loss was found in NPC biopsy tissue in comparison with throat washing samples from healthy individuals ( $\mathrm{OR}=24.60,95 \% \mathrm{CI}=4.42-136.74, p<0.001)$ (Figure 4).

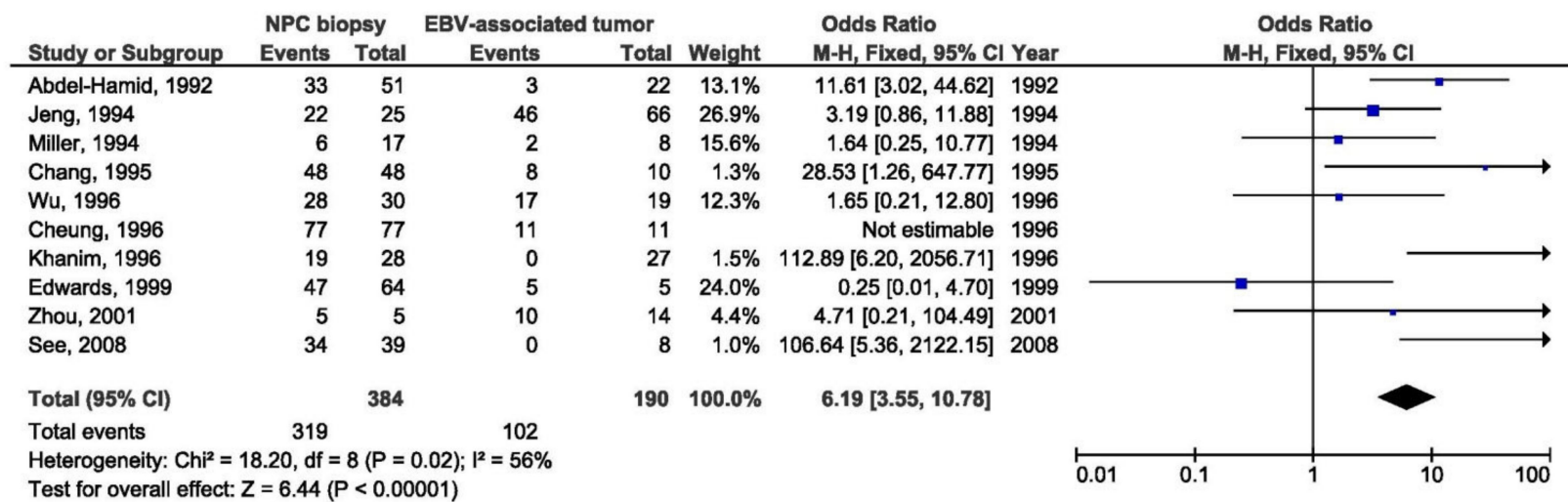

Figure 2. Forest plot of the frequency of the occurrence of Xhol loss in biopsies from NPC and other EBV-associated tumors patients. The confidence interval (CI) was $95 \%$, and the diamond represents the pooled estimate (The blue squares represent point estimation of each study weighted for population size).

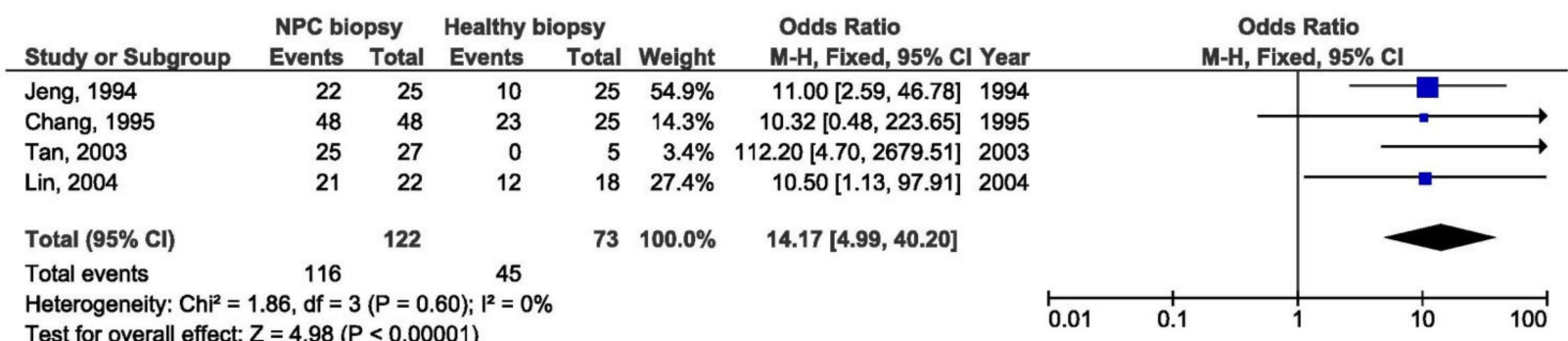

Figure 3. Forest plot of the frequency of the occurrence of Xhol loss in biopsies from NPC and healthy individuals. The confidence interval (CI) was $95 \%$, and the diamond represents the pooled estimate (The blue squares represent point estimation of each study weighted for population size). 


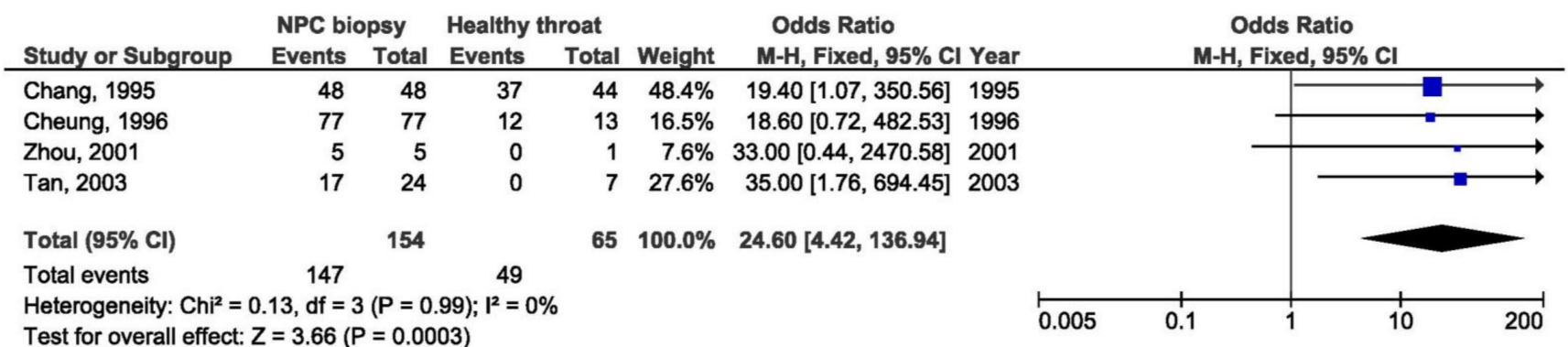

Figure 4. Forest plot of the frequency of the occurrence of Xhol loss in biopsies from NPC and TWs from healthy individuals. The confidence interval (CI) was $95 \%$, and the diamond represents the pooled estimate (The blue squares represent point estimation of each study weighted for population size).

\subsubsection{The $30 \mathrm{bp}$ Deletion}

A total of 27 studies were included in the meta-analysis of the association between 30 bp deletion LMP1 and NPC susceptibility. Due to the great tissue heterogeneity, the meta-analysis was organized in subgroups according to the type of clinical samples. First, this relationship was evaluated between NPC biopsy samples and other specimens (healthy individual's biopsies, healthy individual's throat washings, and EBV-associated non-NPC tumors). Further, it was examined in non-biopsy samples (throat washings and blood) between NPC and healthy controls.

There was a significant association between the $30 \mathrm{bp}$ deletion and NPC susceptibility in two compared groups: NPC biopsy samples and healthy biopsies (OR $=3.53,95 \%$ $\mathrm{CI}=1.48-8.43, p=0.004$ ) (Figure 5). The result of the meta-analysis of the difference in the presence of $30 \mathrm{bp}$ deletion LMP1 variant between NPC biopsy samples and throat washings from healthy respondents showed significantly greater frequency of this variant in NPC biopsies (OR $=3.77,95 \% \mathrm{CI}=2.21-6.44, p<0.001$ ) (Figure 6). However, when we analyzed the association of the $30 \mathrm{bp}$ deletion LMP1 variant with NPC, when comparing biopsies from NPC and other EBV-associated non-NPC tumors, there was not a significant association ( $\mathrm{OR}=1.74,95 \% \mathrm{CI}$ : $0.81-3.75, p=0.160$ ) (Figure 7). In addition, when non-biopsy NPC samples were compared with the same type of the specimen from healthy controls, no statistically significant difference in the frequency of $30 \mathrm{bp}$ deletion LMP1 variant in throat washings nor in peripheral blood samples was found ( $\mathrm{OR}=1.25,95 \% \mathrm{CI}=0.71-2.21$, $p=0.440$ and $\mathrm{OR}=0.82,95 \% \mathrm{CI}=0.18-3.83, p=0.800$, respectively) (Figures 8 and 9).

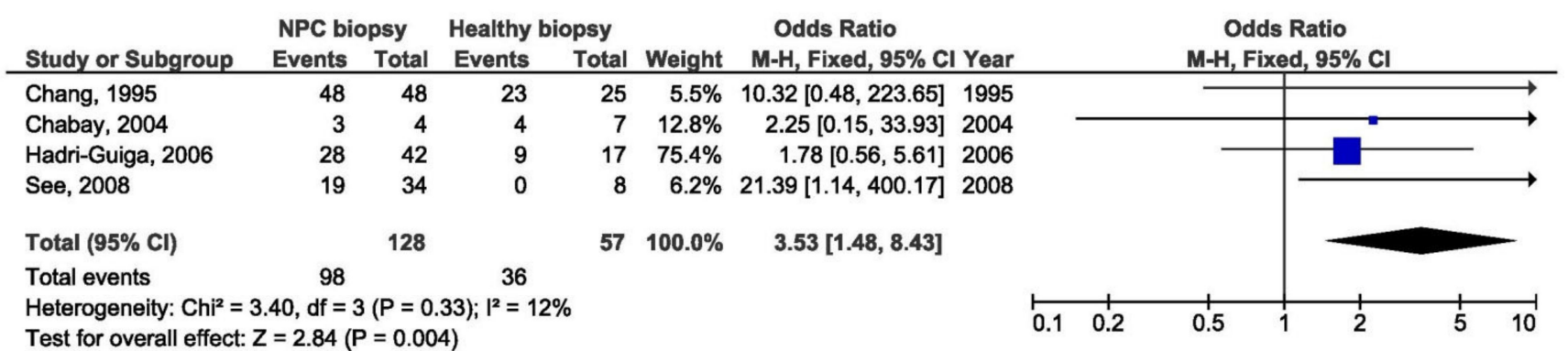

Figure 5. Forest plot of the frequency of the occurrence of $30 \mathrm{bp}$ del in biopsies from NPC and healthy individuals. The confidence interval (CI) was $95 \%$, and the diamond represents the pooled estimate (The blue squares represent point estimation of each study weighted for population size). 


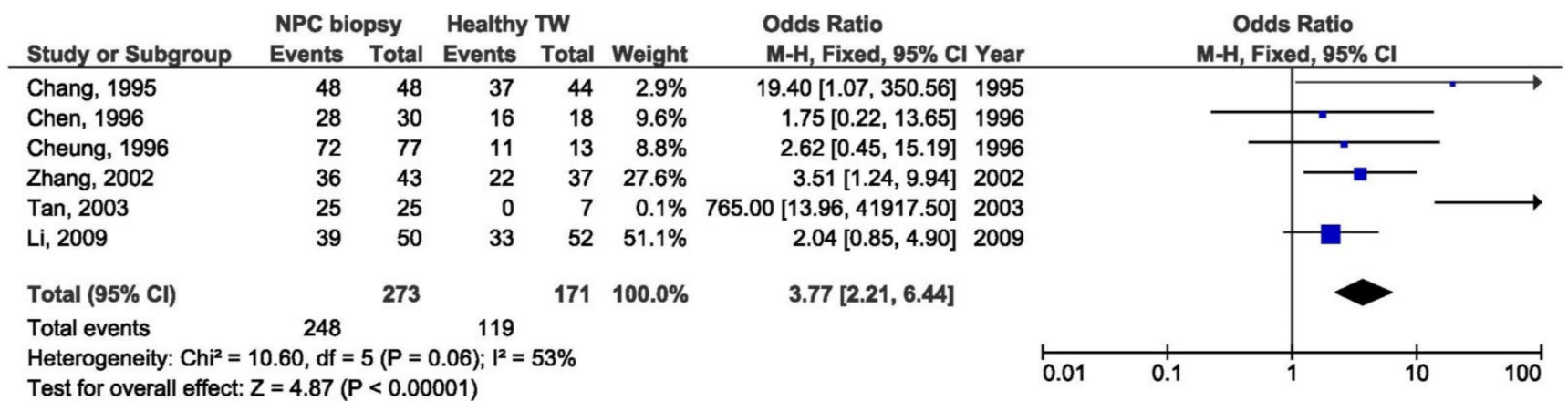

Figure 6. Forest plot of the frequency of the occurrence of $30 \mathrm{bp}$ del in biopsies from NPC and TWs from healthy individuals. The confidence interval (CI) was 95\%, and the diamond represents the pooled estimate (The blue squares represent point estimation of each study weighted for population size).

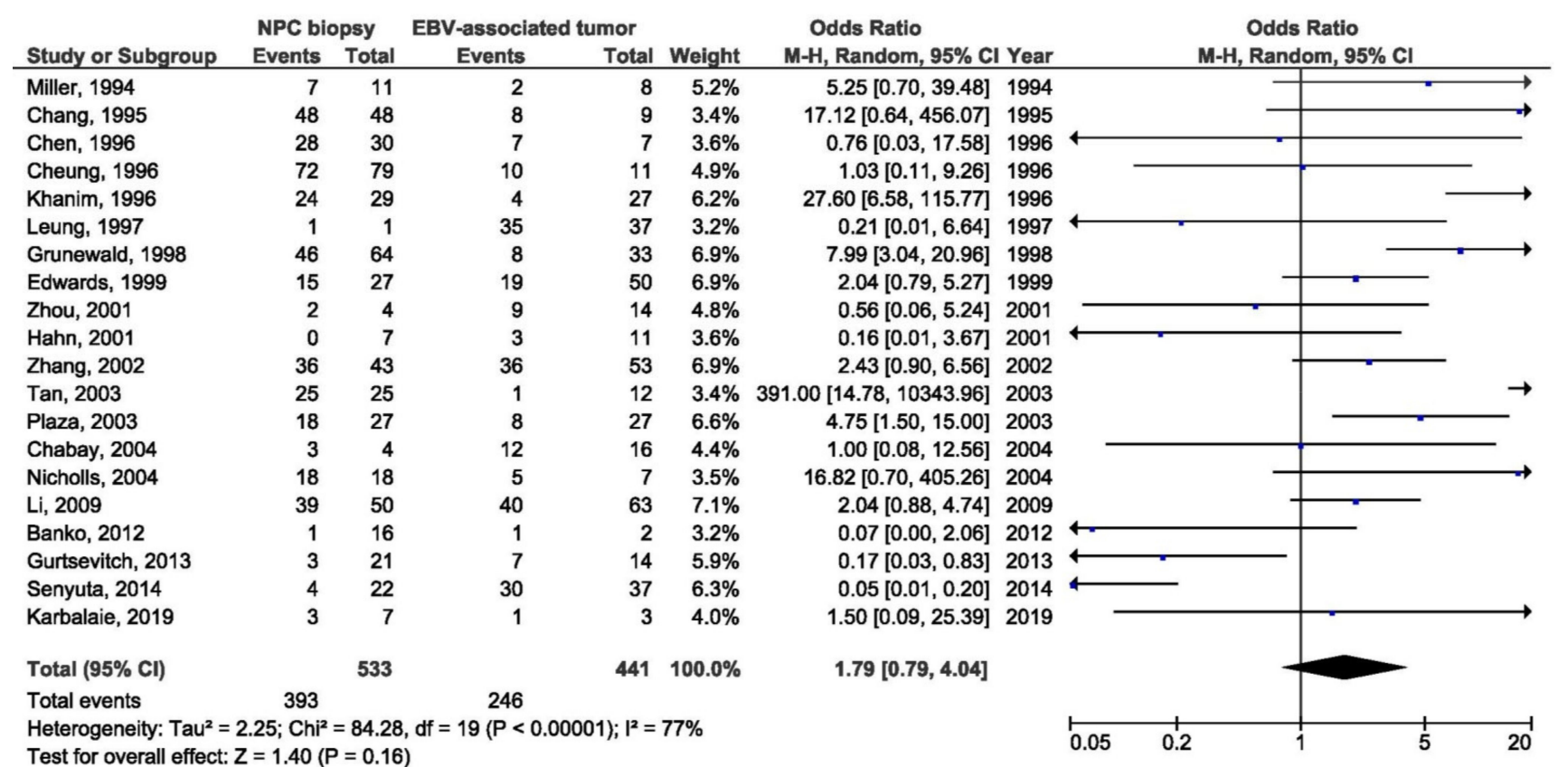

Figure 7. Forest plot of the frequency of the occurrence of $30 \mathrm{bp}$ del in biopsies from NPC and other EBV-associated tumors patients. The confidence interval (CI) was $95 \%$, and the diamond represents the pooled estimate (The blue squares represent point estimation of each study weighted for population size).

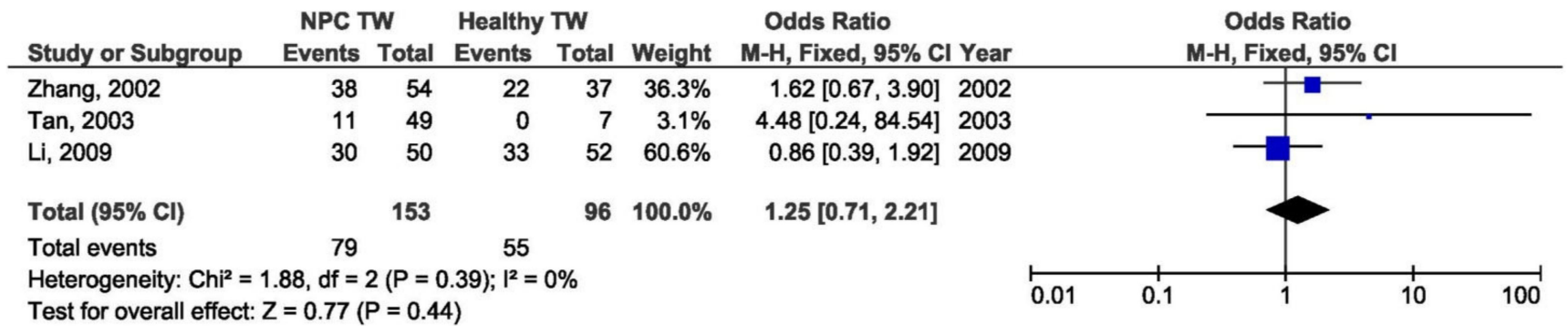

Figure 8. Forest plot of the frequency of the occurrence of $30 \mathrm{bp}$ del in TWs from NPC and healthy individuals. The confidence interval (CI) was $95 \%$, and the diamond represents the pooled estimate (The blue squares represent point estimation of each study weighted for population size). 


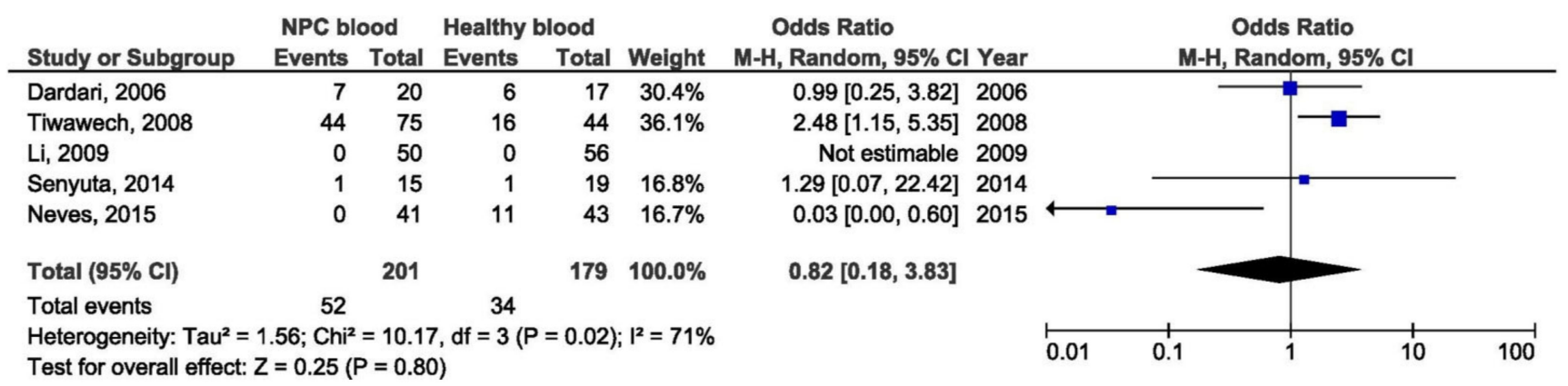

Figure 9. Forest plot of the frequency of the occurrence of $30 \mathrm{bp}$ del in blood from NPC and healthy individuals. The confidence interval (CI) was $95 \%$, and the diamond represents the pooled estimate (The blue squares represent point estimation of each study weighted for population size).

\subsubsection{The $69 \mathrm{bp}$ Deletion}

There were no significant association between $69 \mathrm{bp}$ deletion and NPC susceptibility when comparing biopsies from NPC and other EBV-associated tumors, nor when comparing NPC biopsies and healthy donors blood samples $(\mathrm{OR}=1.70,95 \% \mathrm{CI}=0.63-4.61$, $p=0.290$, and $\mathrm{OR}=2.22,95 \% \mathrm{CI}=0.26-18.60, p=0.460)($ Figures 10 and 11$)$.

\begin{tabular}{|c|c|c|c|c|c|c|c|c|}
\hline \multirow[b]{2}{*}{ Study or Subgroup } & \multicolumn{2}{|c|}{ NPC biopsy } & \multicolumn{2}{|c|}{ EBV-associated tumor } & \multicolumn{3}{|c|}{ Odds Ratio } & \multirow{2}{*}{$\begin{array}{c}\text { Odds Ratio } \\
\text { M-H, Fixed, } 95 \% \text { Cl }\end{array}$} \\
\hline & Events & Total & Events & Total & Weight & M-H, Fixed, $95 \% \mathrm{Cl}$ & Year & \\
\hline Grunewald, 1998 & 3 & 64 & 2 & 33 & $39.3 \%$ & $0.76[0.12,4.80]$ & 1998 & \begin{tabular}{l|l}
$\mathbf{n}$ & \\
\end{tabular} \\
\hline Banko, 2012 & 3 & 16 & 1 & 1 & $33.3 \%$ & $0.09[0.00,2.61]$ & 2012 & \\
\hline Gurtsevitch, 2013 & 6 & 21 & 1 & 14 & $13.4 \%$ & $5.20[0.55,49.02]$ & 2013 & \\
\hline Senyuta, 2014 & 6 & 22 & 1 & 14 & $13.9 \%$ & $4.88[0.52,45.79]$ & 2014 & \\
\hline Total $(95 \% \mathrm{Cl})$ & & 123 & & 62 & $100.0 \%$ & $1.70[0.63,4.61]$ & & \\
\hline Total events & 18 & & 5 & & & & & \\
\hline Heterogeneity: $\mathrm{Chi}^{2}=$ & $47, \mathrm{df}=3$ & $\begin{array}{l}(P=0 . \\
=0.29\end{array}$ & $14) ; 1^{2}=45 \%$ & & & & & 0.01 \\
\hline
\end{tabular}

Figure 10. Forest plot of the frequency of the occurrence of $69 \mathrm{bp}$ del in biopsies from NPC and other EBV-associated tumor patients. The confidence interval (CI) was $95 \%$, and the diamond represents the pooled estimate (The blue squares represent point estimation of each study weighted for population size).

\subsubsection{B95-8 Variant}

B95-8 variant in blood samples from NPC patients was a protective factor for NPCs when comparing with blood specimens from healthy individuals $(\mathrm{OR}=0.06$, $95 \% \mathrm{CI}=0,02-0,17, p<0.001$ ) (Figure 12). In addition, there was no significant association between B95-8 variant and NPC susceptibility when comparing biopsies from NPC and other EBV-associated tumors, but also when comparing throat washing samples from NPC and healthy individuals ( $\mathrm{OR}=1.27,95 \% \mathrm{CI}=0.44-3.67, p=0.660$ and $\mathrm{OR}=0.16$, $95 \% \mathrm{CI}=0.00-5.90, p=0.320$, respectively) (Figures 13 and 14).

\subsubsection{China1 Variant}

A total of six studies were included in the meta-analysis of the association between China1 LMP1 variant and NPC susceptibility. There was a significant inverse association between China1 LMP1 variant and NPC susceptibility when comparing biopsies from NPC and EBV-associated non-NPC tumors (OR $=0.16,95 \% \mathrm{CI}=0.05-0,52, p=0.003$ ) (Figure 15). Otherwise, there was no significant association between China1 LMP1 variant and NPC when comparing blood samples from NPC and EBV-associated non-NPC tumors $(\mathrm{OR}=0.10,95 \% \mathrm{CI}=0.00-2.34, p=0.150)$ (Figure 16), as well as when comparing throat washings from NPC and EBV-associated non-NPC tumors ( $\mathrm{OR}=0.25,95 \% \mathrm{CI}=0.01-7.88$, $p=0.430)$ (Figure 17). 


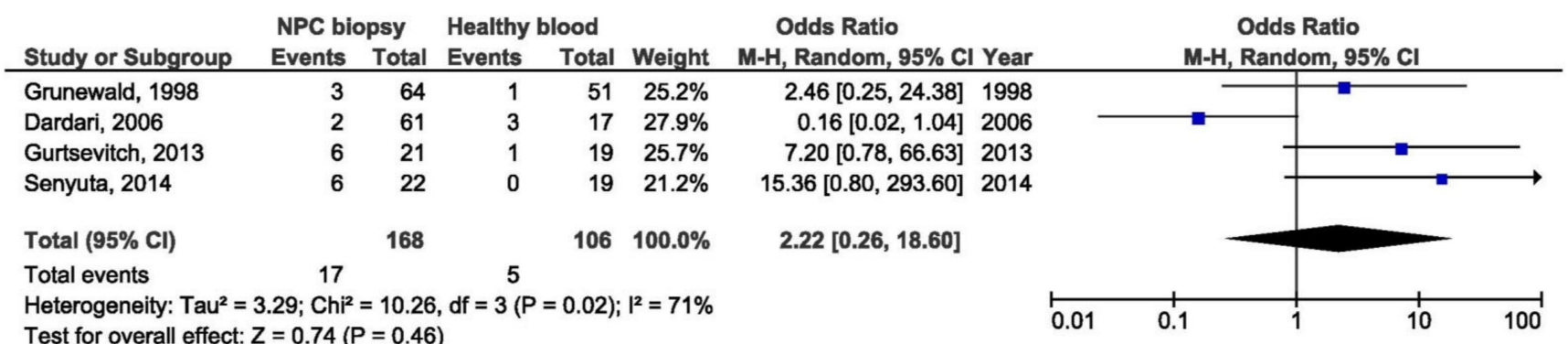

Figure 11. Forest plot of the frequency of the occurrence of $69 \mathrm{bp}$ del in NPC biopsies and blood from healthy individuals. The confidence interval (CI) was $95 \%$, and the diamond represents the pooled estimate (The blue squares represent point estimation of each study weighted for population size).

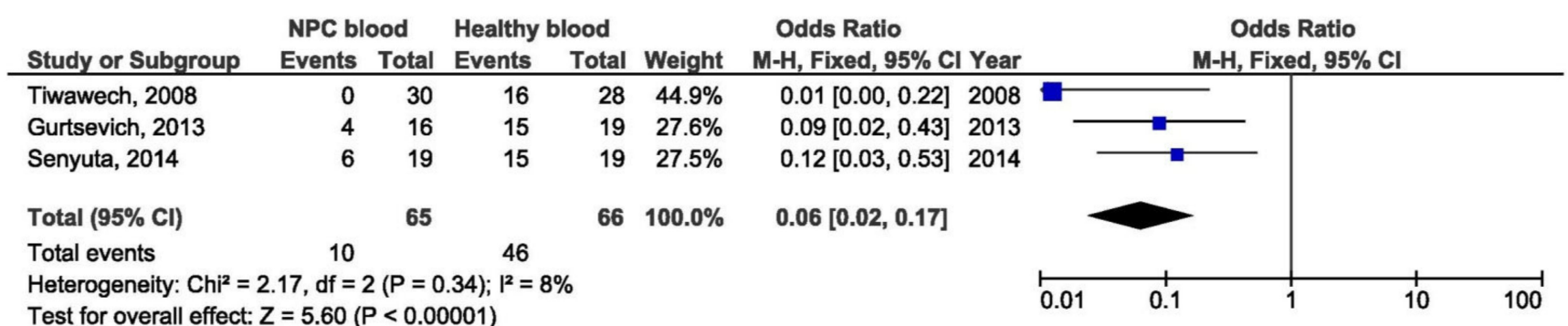

Figure 12. Forest plot of the frequency of the occurrence of B95-8 in blood samples from NPC and healthy individuals. The confidence interval (CI) was $95 \%$, and the diamond represents the pooled estimate (The blue squares represent point estimation of each study weighted for population size).

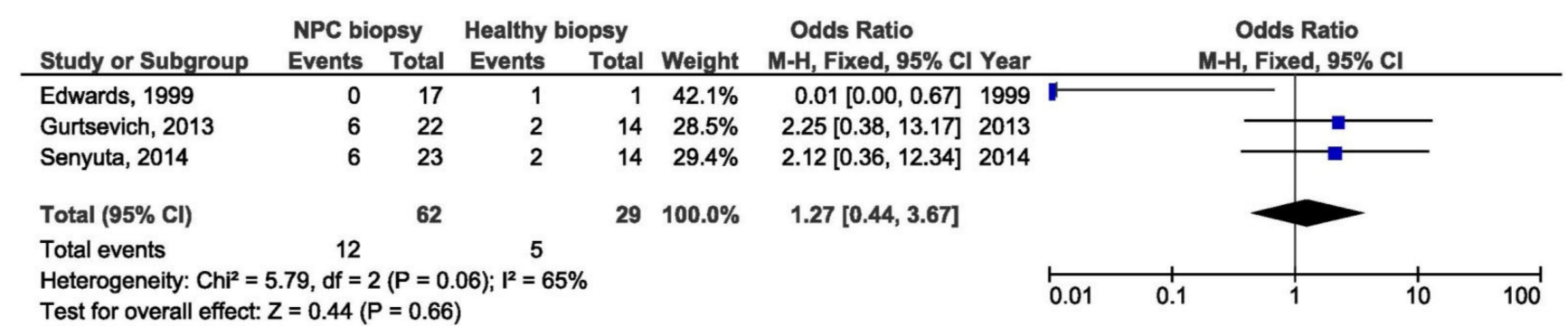

Figure 13. Forest plot of the frequency of the occurrence of B95-8 loss in biopsies from NPC and healthy individuals. The confidence interval (CI) was $95 \%$, and the diamond represents the pooled estimate (The blue squares represent point estimation of each study weighted for population size).

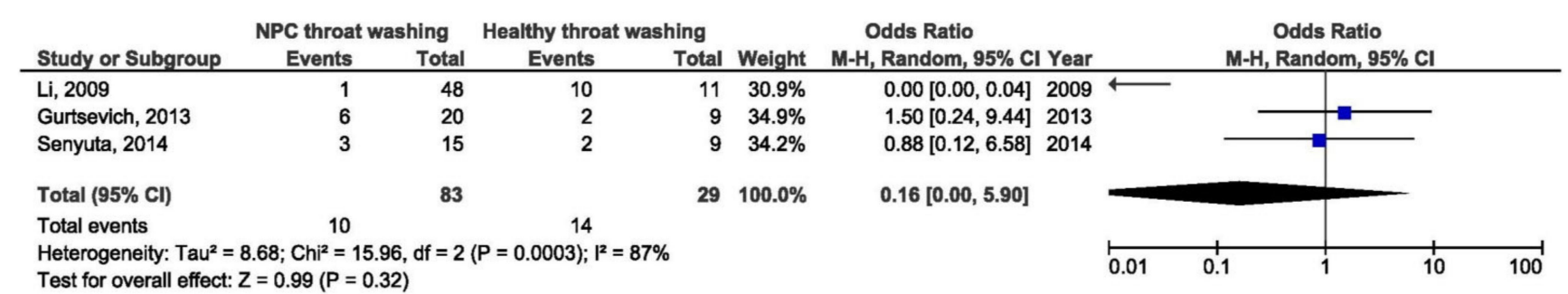

Figure 14. Forest plot of the frequency of the occurrence of B95-8 in TWs from NPC and healthy individuals. The confidence interval (CI) was 95\%, and the diamond represents the pooled estimate (The blue squares represent point estimation of each study weighted for population size). 


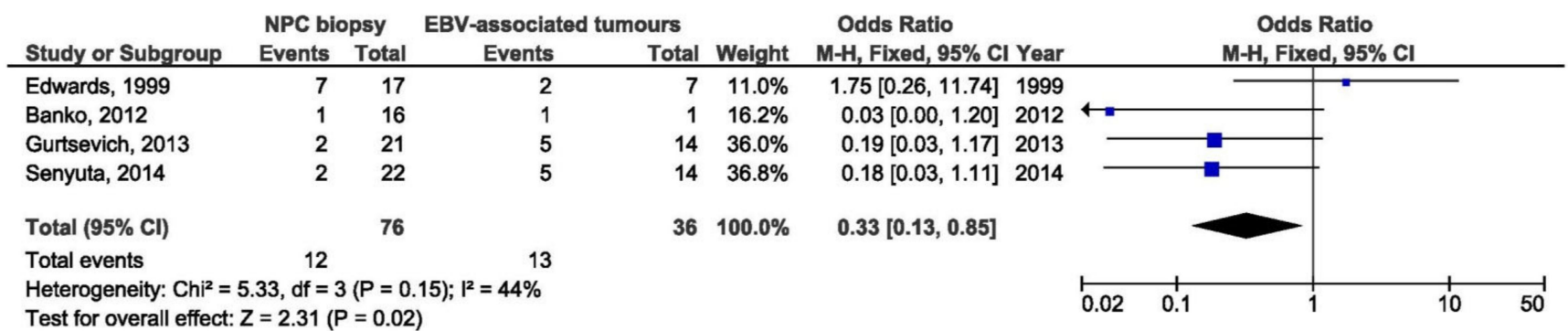

Figure 15. Forest plot of the frequency of the occurrence of China1 in biopsies from NPC and other EBV-associated tumors patients. The confidence interval (CI) was $95 \%$, and the diamond represents the pooled estimate (The blue squares represent point estimation of each study weighted for population size).

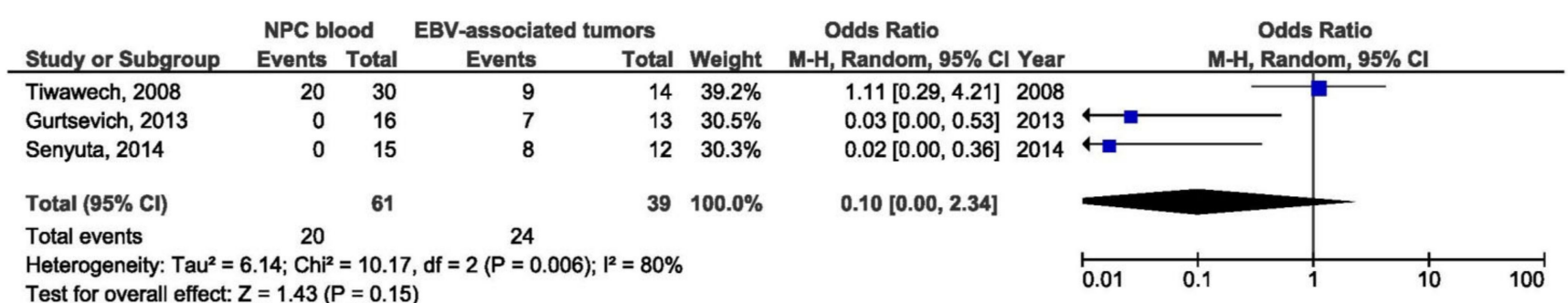

Figure 16. Forest plot of the frequency of the occurrence of China1 in blood samples from NPC and other EBV-associated tumors patients. The confidence interval (CI) was 95\%, and the diamond represents the pooled estimate (The blue squares represent point estimation of each study weighted for population size).

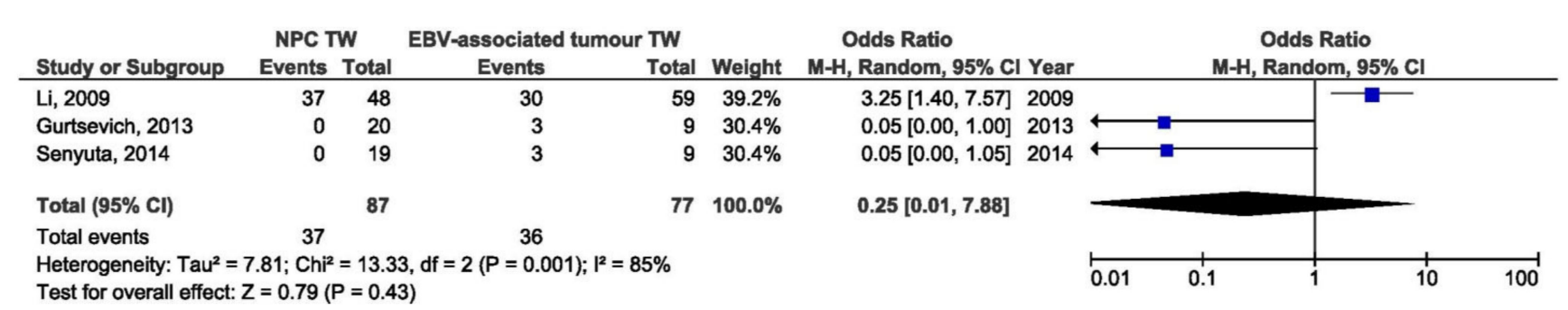

Figure 17. Forest plot of the frequency of the occurrence of China1 in TWs from NPC and other EBV-associated tumors patients. The confidence interval (CI) was $95 \%$, and the diamond represents the pooled estimate (The blue squares represent point estimation of each study weighted for population size).

\subsubsection{Mediterranean (Med) Variant}

A total of six studies were included in the meta-analysis of the association between Med LMP1 variant and NPC susceptibility. There was no association between Med LMP1 variant and NPC when comparing biopsy samples from NPC and EBV-associated nonNPC tumors $(\mathrm{OR}=1.14,95 \% \mathrm{CI}=0.50-2.63, p=0.760)$ (Figure 18). Additionally, no association between Med LMP1 variant and NPC was found when comparing blood samples from NPC and EBV-associated non-NPC tumors $(\mathrm{OR}=2.26,95 \% \mathrm{CI}=0.21-24.18$, $p=0.500$ ) (Figure 19). Med LMP1 variant was not in a relation with NPC as well when comparing throat washings from NPC and EBV-associated non-NPC tumors $(\mathrm{OR}=1.95$, 95\% CI $=0.67-5.69, p=0.220$ ) (Figure 20).

\subsubsection{North Carolina (NC) Variant}

A total of three studies were included in the meta-analysis of the association between North Carolina LMP1 variant and NPC susceptibility. NC LMP1 variant in NPC biopsy 
samples was a protective factor when comparing with other EBV-associated tumor biopsies

$(\mathrm{OR}=0.20,95 \% \mathrm{CI}=0.04-0.90, p=0.040)$ (Figure 21).

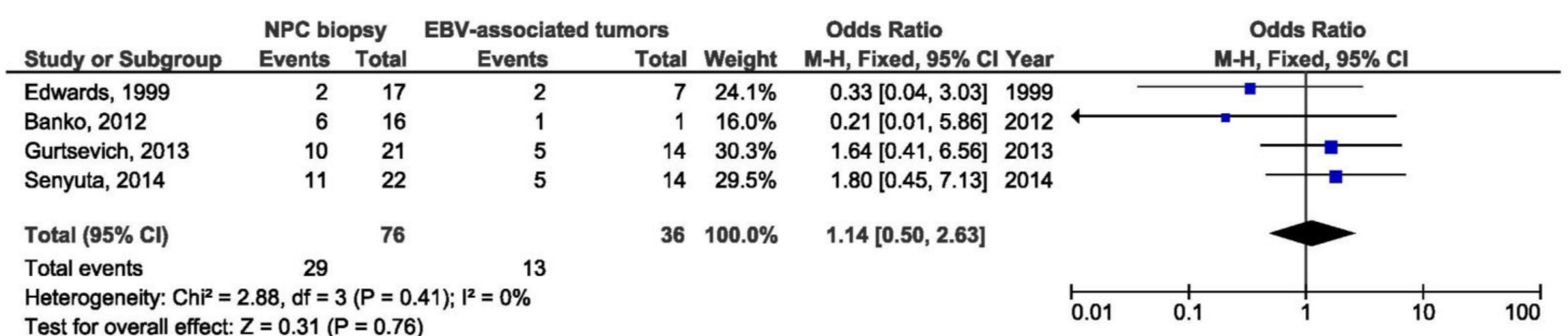

Figure 18. Forest plot of the frequency of the occurrence of Med in biopsies from NPC and other EBV-associated tumors patients. The confidence interval (CI) was $95 \%$, and the diamond represents the pooled estimate (The blue squares represent point estimation of each study weighted for population size).

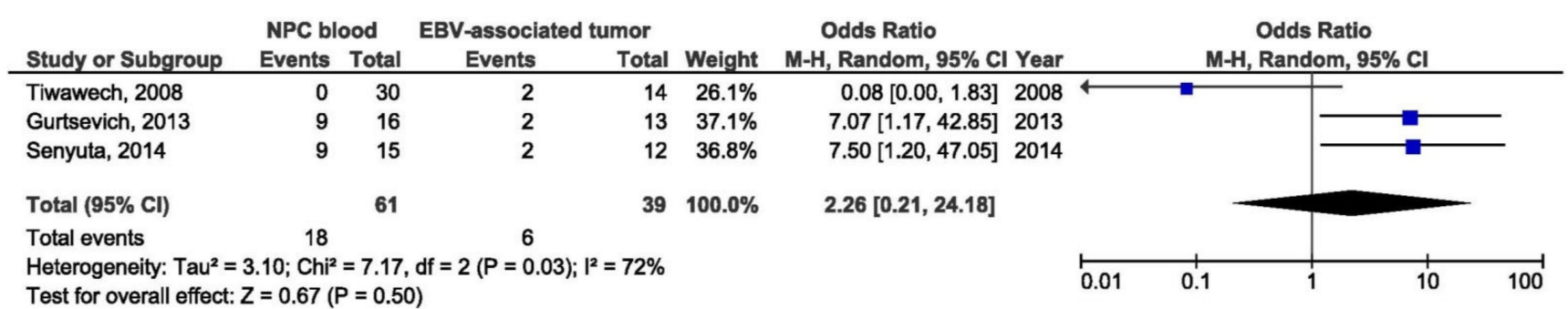

Figure 19. Forest plot of the frequency of the occurrence of Med in blood samples from NPC and other EBV-associated tumors patients. The confidence interval (CI) was 95\%, and the diamond represents the pooled estimate (The blue squares represent point estimation of each study weighted for population size).

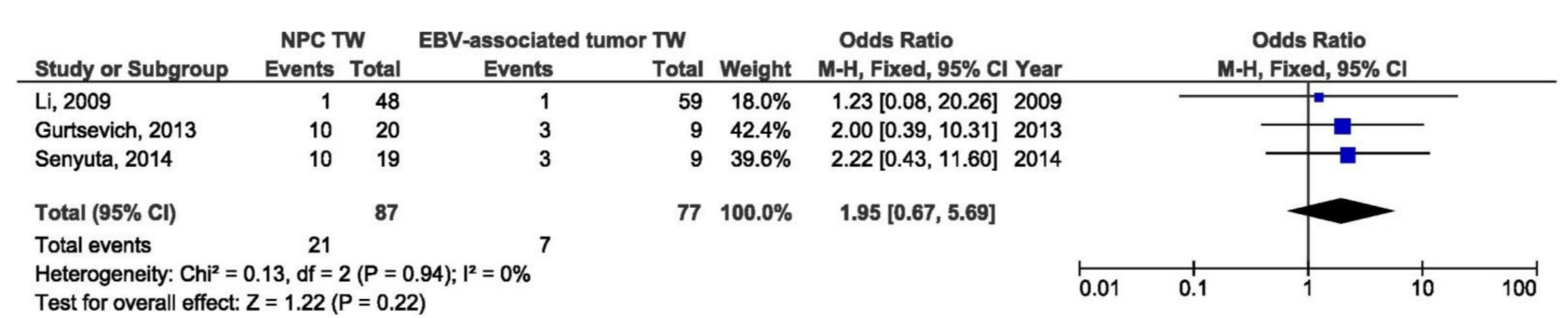

Figure 20. Forest plot of the frequency of the occurrence of Med in TWs from NPC and other EBV-associated tumors patients. The confidence interval (CI) was $95 \%$, and the diamond represents the pooled estimate (The blue squares represent point estimation of each study weighted for population size).

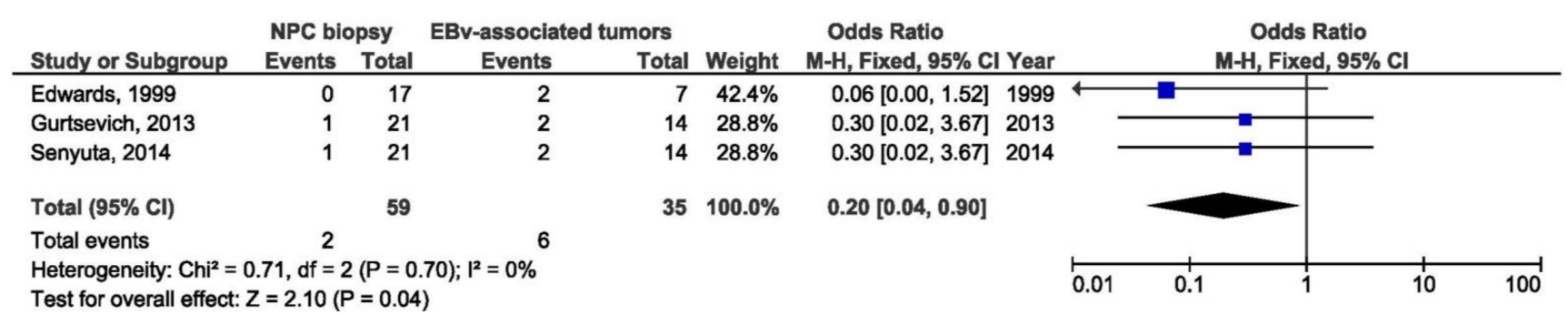

Figure 21. Forest plot of the frequency of the occurrence of NC in biopsies from NPC and other EBV-associated tumors patients. The confidence interval (CI) was $95 \%$, and the diamond represents the pooled estimate (The blue squares represent point estimation of each study weighted for population size). 


\subsection{The Association between LMP1 Variants and NPC Susceptibility by Regions: Endemic and Non-Endemic}

\subsubsection{The $30 \mathrm{bp}$ Deletion}

Further meta-analysis was done by regions: endemic and non-endemic. There was a significant association between $30 \mathrm{bp}$ del LMP1 and the NPC susceptibility in the studies conducted in endemic regions when comparing biopsies from NPC and healthy individuals $(\mathrm{OR}=6.91,95 \% \mathrm{CI}=1.18-40.35, p=0.030)$ (Figure 22), but also when comparing NPC biopsy and throat washings from healthy individuals $(\mathrm{OR}=2.80,95 \% \mathrm{CI}=1.62-4.84$, $p<0.001$ ) (Figure 23). Otherwise, there was no significant difference in the prevalence of $30 \mathrm{bp}$ del in studies from endemic regions when comparing biopsies from NPC and EBV-associated non-NPC tumors $(\mathrm{OR}=1.59,95 \% \mathrm{CI}=0.83-3.06, p=0.170)$ (Figure 24).

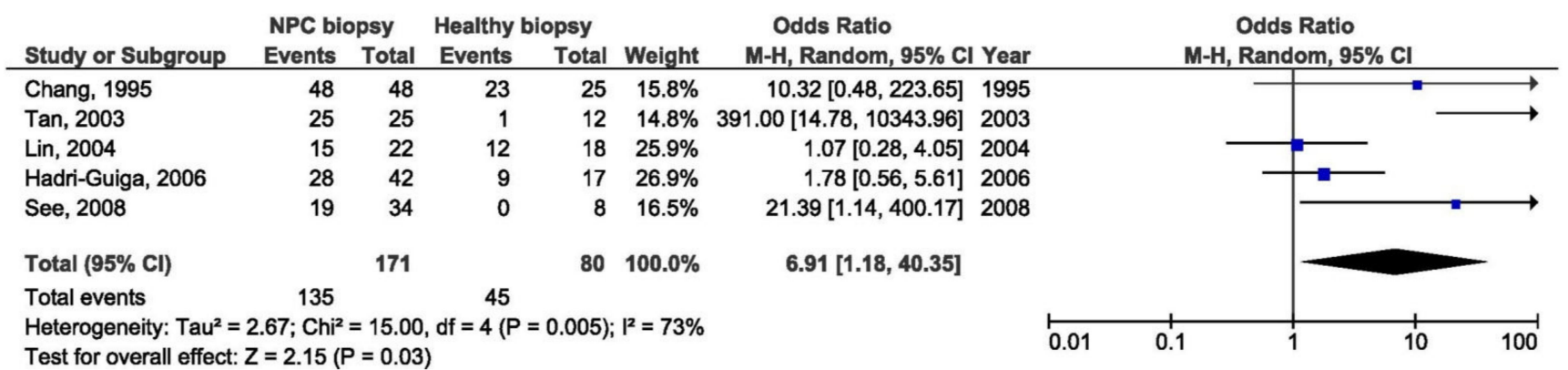

Figure 22. Forest plot of the frequency of the occurrence of $30 \mathrm{bp}$ del in biopsies from NPC and healthy individuals in endemic regions. The confidence interval (CI) was 95\%, and the diamond represents the pooled estimate (The blue squares represent point estimation of each study weighted for population size).

Additionally, there was no association between $30 \mathrm{bp}$ del and NPC susceptibility in studies from non-endemic regions when comparing biopsies from NPC and EBV-associated non-NPC tumors patients $(\mathrm{OR}=0.67,95 \% \mathrm{CI}=0.33-1.36, \mathrm{p}=0.260)$ (Figure 25).

\subsubsection{Xhol Loss}

It was shown that Xhol loss was in statistically significant relation with NPC when comparing biopsies from NPC and EBV-associated non-NPC patients from non-endemic regions ( $\mathrm{OR}=11.84,95 \% \mathrm{CI}=2.32-60.45, p=0.003$ ) (Figure 26), but there was no association between Xhol loss and the NPC susceptibility when comparing biopsies from NPC and EBV-associated non-NPC patients from endemic regions $(\mathrm{OR}=2.10,95 \% \mathrm{CI}=0.94-4.68$, $p=0.070$ ) (Figure 27).

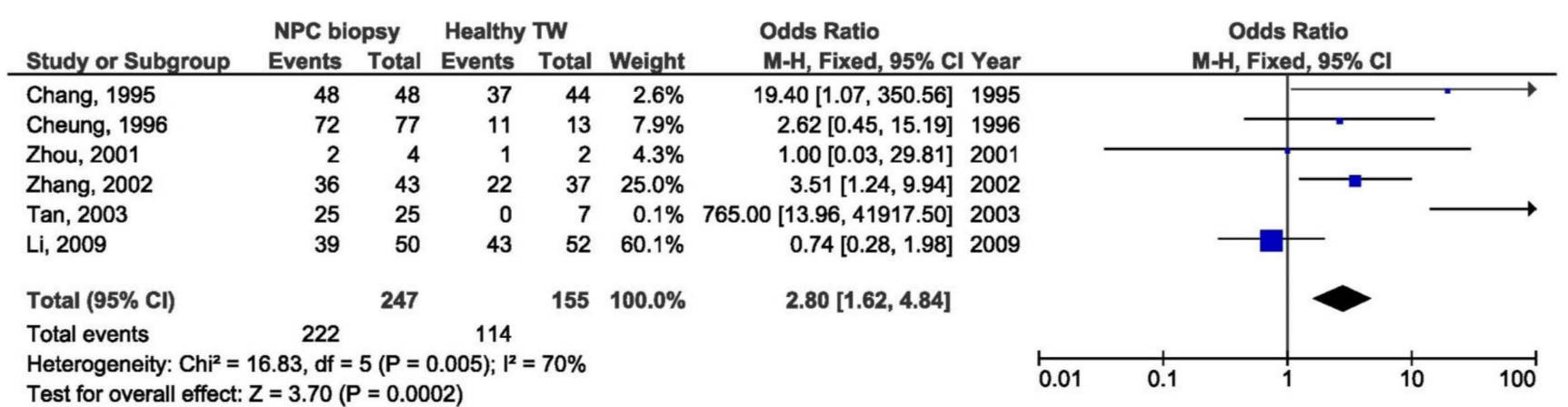

Figure 23. Forest plot of the frequency of the occurrence of $30 \mathrm{bp}$ del in NPC biopsies and TWs from healthy individuals in endemic regions. The confidence interval (CI) was 95\%, and the diamond represents the pooled estimate (The blue squares represent point estimation of each study weighted for population size). 


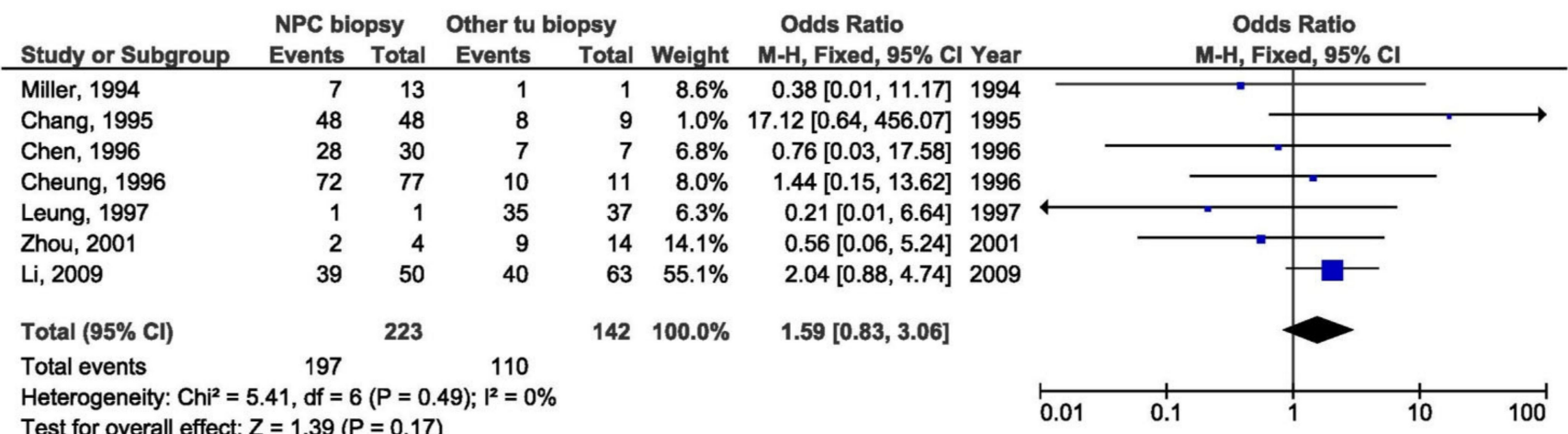

Figure 24. Forest plot of the frequency of the occurrence of $30 \mathrm{bp}$ del in biopsies from NPC and other EBV-associated tumors patients in endemic regions. The confidence interval (CI) was $95 \%$, and the diamond represents the pooled estimate (The blue squares represent point estimation of each study weighted for population size).

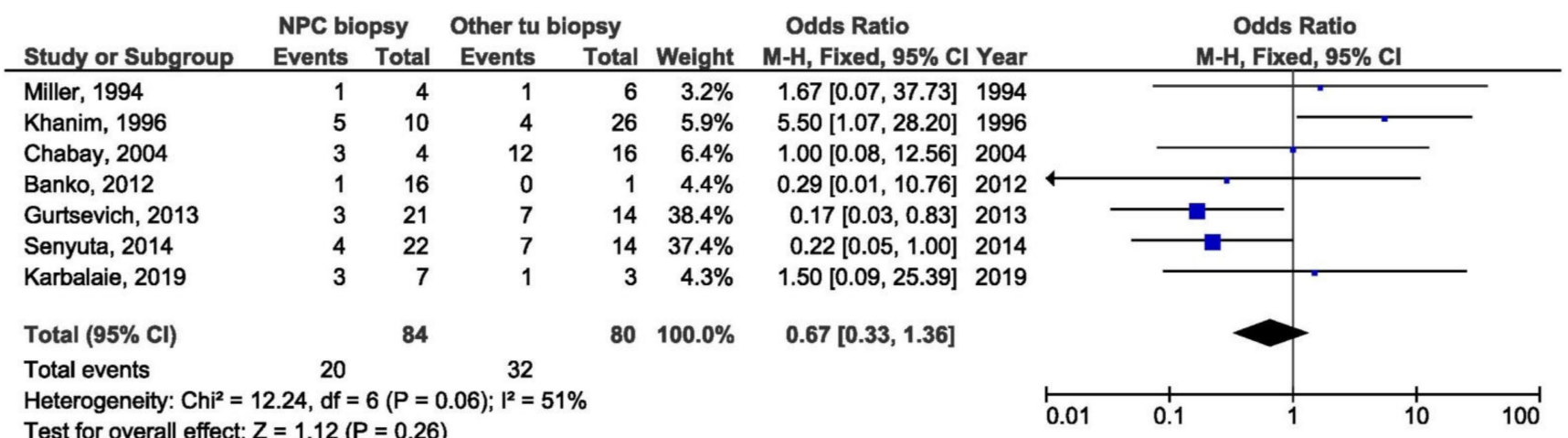

Figure 25. Forest plot of the frequency of the occurrence of $30 \mathrm{bp}$ del in biopsies from NPC and other EBV-associated tumors patients in non-endemic regions. The confidence interval (CI) was $95 \%$, and the diamond represents the pooled estimate (The blue squares represent point estimation of each study weighted for population size).

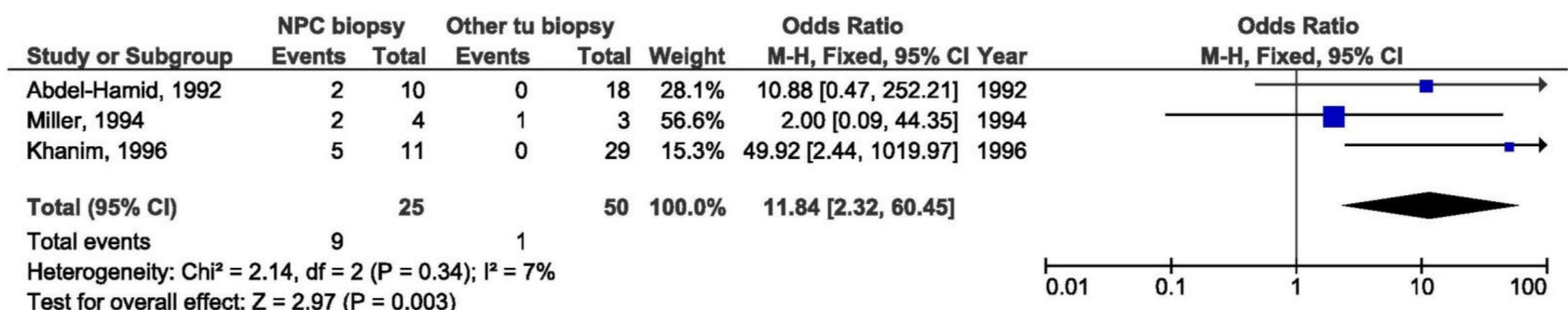

Figure 26. Forest plot of the frequency of the occurrence of Xhol loss in biopsies from NPC and other EBV-associated tumors patients in non-endemic regions. The confidence interval (CI) was $95 \%$, and the diamond represents the pooled estimate (The blue squares represent point estimation of each study weighted for population size). 


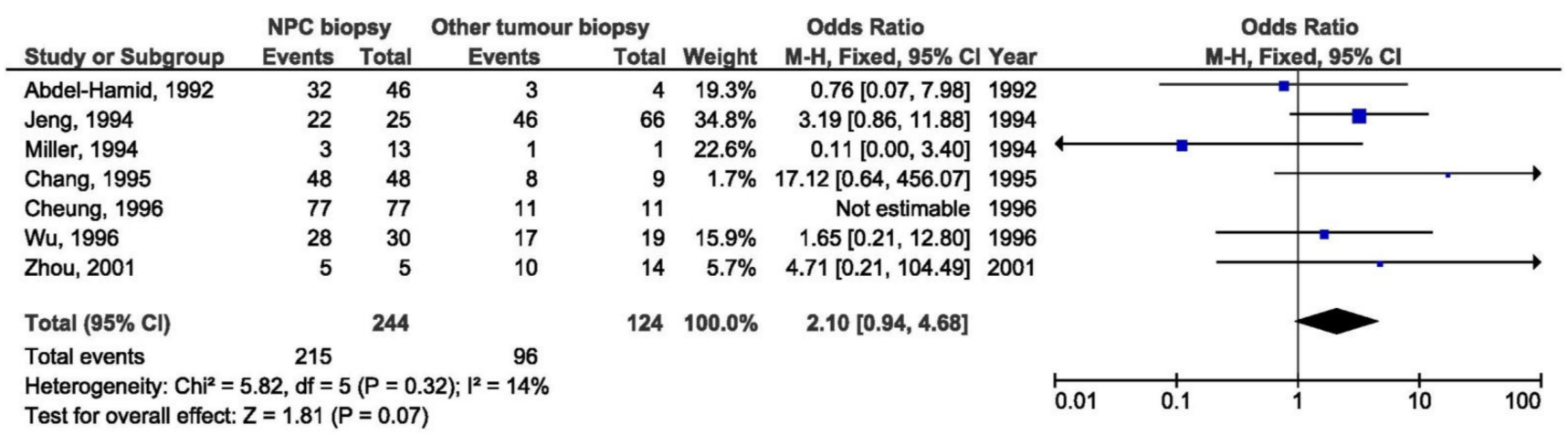

Figure 27. Forest plot of the frequency of the occurrence of Xhol loss in biopsies from NPC and other EBV-associated tumors patients in endemic regions. The confidence interval (CI) was $95 \%$, and the diamond represents the pooled estimate (The blue squares represent point estimation of each study weighted for population size).

\section{Discussion}

This study provided a comprehensive systematic review of LMP1 gene variability, not only between NPC and non-NPC participants in general, but a much more homogeneous and detailed comparison. For the first time, a comparative analysis of LMP1 gene variability included seven variants: Xhol loss, 30 bp and 69 bp deletions, B95-8, China1, Mediterranean, and North Carolina variants, which were presented in different tumor-altered and healthy tissues. Finally, a comparison of the frequency of LMP1 gene variants was also made in relation to geographical origin of the clinical sample.

The course of the NPC pathogenesis is influenced by several factors, among which are genetic susceptibility, environmental and viral factors. As far as viral factors are concerned, EBV and Human papilloma virus (HPV) infections are the most investigated and mentioned in this context. Only recently, the results of meta-analysis designed to establish the relationship between viral combinations in NPC stratified according to histological type have been published [50]. While keratinizing NPC subtype (WHO type I) is found mainly in non-endemic areas, in endemic areas with a high incidence of disease, the majority of cases are non-keratinizing subtypes (WHO types II and III) [51]. Even though keratinizing NPC subtype is often HPV positive, no clear association has been established yet $[52,53]$. On the other hand, non-keratinizing NPC subtypes are almost always EBV positive and proven to be associated with EBV infection [54]. In addition, EBV has been linked to a wide range of other lymphoid and epithelial cell malignancies such as posttransplant lymphoproliferative disease (PTLD), Burkitt's, Hodgkin's and nasal natural killer/T-cell lymphomas, and gastric adenocarcinoma [54].

Several different viral oncogenes such as LMP1, LMP2, and EBNA1 play an important role in the pathogenesis of EBV-associated tumors. The majority of the studies, concerning EBV genetic variability, have focused attention and investigation on LMP1 gene polymorphisms, which is at the same time the most important EBV oncogene but also the most variable gene. Having this in mind, a previous meta-analysis determined the impact of $30 \mathrm{bp}$ deletion and Xhol loss on the risk for NPC development [12]. The authors found that there was a positive association between $30 \mathrm{bp}$ deletion and Xhol loss and NPC susceptibility, but without confirmation that these two LMP1 variants could be considered and used as specific markers of the NPC. Actually, $30 \mathrm{bp}$ deletion and Xhol loss were also detected in control groups and in the other EBV-associated cancers. Our study confirmed the previous data, but with the significantly greater association. Particularly, $30 \mathrm{bp}$ deletion was found 3.5 or 3.8 times more frequently in the NPC biopsies than in the biopsies or TWs from healthy people, respectively. The association between Xhol loss and the NPC susceptibility was much stronger because the presence of Xhol loss in the NPC biopsies was even 14 times higher than in healthy tissue, and as many as 24.6 times than in TWs from healthy individuals. Those frequencies are significantly higher than 8.5 which was 
reported by previous meta-analysis although some literature data reported the complete absence of Xhol loss in the healthy population [12,26].

The systematic classification of the clinical samples' origin and their comparative analysis improved the validity of results obtained in this study. Therefore, it becomes clearer that the specificities of the viral genome are primarily related to tumor-altered tissue, not only NPC but also tissues of the other EBV-related tumors which were included and analyzed in this meta-analysis. Thus, from our results, it could be seen that the association between the LMP1 deleted variant and NPC was seen in viral genome which was localized in the tumor-altered tissue itself, and that it is absent when the frequency of $30 \mathrm{bp}$ deletion is compared with any other type of clinical sample. These findings support published data about the time specific and determined role of EBV oncogenic activity in early phases of NPC development $[55,56]$. Actually, it is very striking that the viral genome is present and transcriptionally active in every tumor cell, while the healthy nasopharyngeal tissue could not be normally infected with EBV and hardly be able to be a reservoir of latent EBV infection [54]. One of the theories about establishing stable latent EBV infection in pre-neoplastic changes in nasopharyngeal epithelium is based on enforced over-expression of cyclin $\mathrm{D}$ in those cells [57]. When the reports about the direct influence of $30 \mathrm{bp}$ deleted LMP1 variant of EBV on the aggressiveness of the carcinogenesis is added to previously mentioned knowledge, it could be assumed that functional differences between LMP1 variants significantly affect the triggering of the cell transformation [58]. It is therefore important to note that the presence of other deletions, such as $69 \mathrm{bp}$, have no significance in relation to NPC or any other EBV-related tumor development which is also confirmed by this meta-analysis [59].

Extensive research of LMP1 gene heterogeneity has so far defined more than seven different strains. The functional differences between the LMP1 of epithelial cancer-derived EBV, which belongs to China1, and lymphoid-derived EBV, which belongs to B95-8, are well described [60]. However, except the fact that nomenclature of these variants reflects their geographic origin or the location from where they were found and dominate in frequency, none of the mentioned variants could be associated with nasopharyngeal carcinoma in this or previous studies. On the other hand, it is interesting that some of the variants could still be considered as a protective factor for NPC. Thus, the results of this metaanalysis showed that China1 and NC could be considered as protective factors for NPC when comparing to other EBV-associated tumors, and B95-8 variant as a protective factor for NPC when comparing to healthy people. The principle of existence of the so-called "eliminated variants" is described by negative immune selection against the presence of other variants within the tumor [61]. For example, the absence of the North Carolina variant within NPC was explained by the inability of the NC to inhibit T-cell proliferation and natural killer cytotoxicity because of unique mutations in the region of LMP1 gene responsible for immunosuppressive function [61].

Meta-analysis by regions reveals that the presence of $30 \mathrm{bp}$ deletion in the NPC biopsies was almost seven times higher than in healthy tissue in endemic regions. As it has long been postulated that distinct EBV strains are predominant in areas with a high incidence of the NPC, and that EBV strain variation contributes to the endemic nature of the NPC, 30 bp deletion and Xhol loss in these areas could serve as prognostic markers for tumor development [21,62]. This includes the NPC or other EBV-associated tumors since in this study no difference has been shown in association between $30 \mathrm{bp}$ deletion or Xhol loss and either the NPC susceptibility or other EBV-associated tumors susceptibility according to tissue biopsy findings. On the other hand, in non-endemic regions of the NPC, the presence of Xhol loss in NPC biopsies was almost 12 times higher than in the other EBV-associated tumor biopsies. Whether these results from non-endemic regions covered mainly keratinizing subtypes of the NPC with better prognosis remains to be further examined and analyzed in order to potentially define "less oncogenic" and "more oncogenic" EBV variants [54]. 
As the EBV genetic variability led to the increasing interest of possible disease-specific associations with EBV variants, but still too diverse to single out the individual risk factors, new high-throughput sequencing technologies marked a new era of EBV sequencing. Therefore, a recent explosive increase in EBV whole genome sequences could open the window of new opportunities in EBV genome research, and lead to identification of high-risk groups of people who are predisposed to the NPC and impact on the early diagnosis of the NPC [63]. In addition, it could also determine a new path of EBV taxonomy and classification.

This is not the first, but it is a comprehensive meta-analysis of the association between LMP1 variants and the NPC susceptibility. Regardless of its advantages, some limitations were recognized. First, only articles in English were included (there were 67 articles in other languages). Second, abstracts were not taken into account. The first and the second reason might lead to making a selection bias and losing the data. In order to examine publication bias, Funnel plots were performed, and they indicated no publication bias. Third, there was great heterogeneity in types of clinical samples, so it was chosen to do meta-analysis in subgroups, according to the types of clinical samples taken from NPC and control groups to make more homogeneous conclusions. Fourth, the number of studies in each meta-analysis was different. Some of them, with smaller number of included studies (three) had smaller statistical power than those with greater number of included articles. Fifth, because of the scarcity of data with potential influence on the association between LMP1 variants and NPC susceptibility, such as age and gender, we were not able to perform the meta-regression analysis in order to control the estimated effect size (OR) and avoid underestimation and overestimation in these situations. Sixth, regardless of the duration of performing studies on the association between LMP1 variants and NPC (from 1973 to today) there was not enough survival data in order to perform meta-analysis of hazards.

In summary, the results from this study give a proof of concept for the association between two LMP1 variants (30 bp deletion and Xhol loss) and the NPC susceptibility when comparing biopsies from the NPC and healthy individuals. Moreover, this association was also found with other EBV-associated tumors. Otherwise, 30 bp deletion from NPC biopsies could not distinguish NPC from EBV-associated non-NPC tumors. On the other hand, B95-8, China1 and North Carolina variants were uncommon for NPC individuals. Although it is clear that not only EBV LMP1 gene variability but also many other non-viral factors are involved in the etiopathogenesis of the NPC, the importance of identification of so-called "high-risk" EBV variants could be crucial in defining relative variant tropism, designing targeted antiviral candidates or even make progress toward an EBV vaccine. Over the past decades, numerous efforts have been made, but much more work remains to be done to verify the biological significance of the differences observed and make it available for clinical application.

\section{Materials and Methods}

This systematic review was performed in accordance with the PRISMA protocol (Reporting Items for Systematic Reviews and Meta-Analyses) and MOOSE guidelines for observational studies after systematic review registration at PROSPERO (Systematic review registration statement is available at https: / / osf.io/znrwj/) [64,65].

\subsection{Study Selection}

Publications were screened for inclusion in the systematic review in two phases, and all disagreements were resolved by discussion at each stage with inclusion of a third reviewer. We included studies that detected LMP1 gene variants in patients with nasopharyngeal carcinoma and any other group for comparison. Studies were eligible for inclusion if LMP1 gene variants were detected in both groups. Studies were excluded if they (i) investigated other outcomes, (ii) did not make comparisons between patients with nasopharyngeal carcinoma and control groups, (iii) examined other populations (animal, cell lines), (iv) 
assessed other genes (LMP2, EBNA-1, etc.), (v) did not assess LMP1 variants, but its function or expression, (v) were abstracts, or (vi) were not original articles.

\subsection{Database Search}

Two biostatisticians with expertise in conducting systematic reviews and meta-analyses (AC, DM) developed the search strategy. A systematic review of peer-reviewed publications was performed through searches of PubMed, Web of Science (WoS) and SCOPUS electronic databases until 28 April 2021. Search queries differed according to the database. Keywords for the PubMed search were (Nasopharyngeal carcinoma or Nasopharyngeal neoplasm*) and (Epstein Barr Virus or Epstein-Barr Virus or EBV or Burkitt's lymphoma virus or Herpesvirus 4, human or HHV4) and (TNF receptor associated factor 2 or LMP1Associated Protein 1 or LMP1 or variant or mutation or deletion or polymorphism); for WoS: $\mathrm{ALL}=\left(\right.$ Nasopharyngeal carcinoma OR Nasopharyngeal neoplasm $\left.{ }^{*}\right)$ AND ALL $=($ Epstein Barr Virus OR Epstein-Barr Virus OR EBV OR Burkitt's lymphoma virus OR Human herpesvirus 4 OR HHV4) AND ALL = (TNF Recept associated factor 2 OR LMP1-Associated Protein 1 OR LMP1 or variant or mutation or deletion or polymorphism), and for SCOPUS: (TITLE-ABS-KEY ("Nasopharyngeal carcinoma") OR TITLE-ABS-KEY ("Nasopharyngeal neoplasm*") AND TITLE-ABS-KEY ("Epstein Barr Virus") OR TITLE-ABS-KEY ("EpsteinBarr Virus") OR TITLE-ABS-KEY ("EBV”) OR TITLE-ABS-KEY ("BURKITT'S LYMPHOMA VIRUS") OR TITLE-ABS-KEY ("Human herpesvirus 4") OR TITLE-ABS-KEY ("HHV4") AND TITLE-ABS-KEY ("TNF RECEPT ASSOCIATED FACTOR 2") OR TITLE-ABS-KEY ("LMP1-Associated Protein 1") OR TITLE-ABS-KEY ("LMP1") OR TITLE-ABS-KEY ("variant") OR TITLE-ABS-KEY ("mutation") OR TITLE-ABS-KEY ("deletion") OR TITLE-ABSKEY ("polymorphism"). Only publications in English were taken into account. In addition, reference lists of articles identified through electronic retrieval were manually searched, as well as relevant reviews and editorials. Experts in the field were contacted to identify other potentially relevant articles. Authors of relevant articles were contacted to obtain missing data.

\subsection{Article Screening and Selection}

Two reviewers (A.C., D.M.) independently evaluated the eligibility of all titles and abstracts. Studies were included in the full text screening if either reviewer identified the study as being potentially eligible, or if the abstract and title did not include sufficient information. Studies were eligible for full text screening if they included detection of LMP1 gene variants in patients with nasopharyngeal carcinoma and control group. The same reviewers independently performed full text screening to select articles for inclusion according to the criteria listed under Inclusion and Exclusion Criteria. Disagreements were resolved by consensus (A.C., D.M.) or arbitration (A.B., I.L.).

\subsection{Data Abstraction and Quality Assessment}

Two reviewers independently abstracted the following data: author(s), country of research, year of publication, study design, sample size, study population, EBV positivity, type of LMP1 gene variant, method for detection of LMP1 gene variant. Each reviewer independently evaluated the quality of selected manuscripts using an adapted version of the Newcastle-Ottawa tool for observational studies [66]. Reviewers used a standardized previously defined LMP1 variant protocol when selecting and abstracting data. All detailed information about reasons for inclusion/exclusion and quality assessment are available at https://osf.io/znrwj/.

\subsection{Statistical Analysis}

The primary outcome was the frequency of LMP1 gene variants. As the outcome is dichotomous and the sample size varies Mantel-Haenszel method was used as a measure of effect size to examine the differences in ratio of a specific LMP1 gene variant in evaluated study groups from all primary articles. Mantel-Haenszel method is a fixed-effect meta- 
analysis method that uses a different weighting scheme that depends on which effect measure is being used. Heterogeneity was assessed using the Chi-square $Q$ test and I2 statistic. I2 presents the inconsistency between the study results and quantifies the proportion of observed dispersion that is real, i.e., due to between-study differences and not due to random error. The categorization of heterogeneity was based on the Cochrane Handbook [67] and states that I2 $<30 \%, 30 \%$ to $60 \%$ or $>60 \%$, corresponds to low, moderate and high heterogeneity, respectively. Forest plots were constructed for each analysis showing the OR (box), 95\% confidence interval (lines), and weight (size of box) for each trial. The overall effect size was represented by a diamond. Due to great heterogeneity of control groups, meta-analysis was performed as a subgroup analysis. According to the available data for $30 \mathrm{bp}$ deletion LMP1 variant we performed the following comparisons: NPC biopsy vs. Other EBV-associated tumors biopsy, NPC biopsy vs. Healthy individual's biopsy, NPC biopsy vs. Throat washing of healthy individuals, NPC blood vs. Healthy individual blood, NPC throat washings vs. Healthy individual's throat washings. For the Xhol loss variant the following comparisons were performed: NPC biopsy vs. EBVassociated non-NPC tumors, NPC biopsy vs. Healthy individual's biopsy, and NPC biopsy vs. Healthy individual's throat washings. It was possible to perform three comparisons for China1 variant: NPC biopsy vs. EBV-associated non-NPC tumors biopsy, NPC blood vs. Healthy individual's blood, and NPC throat washings vs. EBV-associated non-NPC throat washings. For North Carolina (NC) variant only one comparison was possible-NPC biopsy vs. EBV-associated non-NPC tumors biopsy. Three comparisons were done for B95-8 variant: NPC biopsy vs. EBV-associated non-NPC tumors biopsy, NPC blood vs. Healthy individual's blood, and NPC throat washings vs. Healthy individual's throat washings. It was possible to perform three comparisons for Med variant: NPC biopsy vs. EBV-associated non-NPC tumors biopsy, NPC blood vs. Healthy individual's blood, and NPC throat washings vs. EBV-associated non-NPC throat washings. Additionally, for 69 bp deletion two comparisons were performed: NPC biopsy vs. EBV-associated non-NPC tumors and NPC biopsy vs. Healthy individuals blood samples. Additionally, meta-analysis within endemic and non-endemic regions was performed. Southern China and Hong Kong, Southeast Asia, North Africa and the Arctic are considered endemic regions (Wu, 2018). Publication bias was evaluated by Funnel plot for every outcome (available at https://osf.io/znrwj/.). A $p$ value $<0.05$ was considered to be statistically significant. Analyses were performed using Review Manager Version 5.4 [68].

Supplementary Materials: The following are available online at https:/ / www.mdpi.com/article/10 .3390 / pathogens10081057/s1, Table S1: Summary of findings.

Author Contributions: Conceptualization, A.C., A.B.; methodology and software A.C., A.B., D.M., I.L.; analysis A.C.; writing — original draft preparation, A.B., D.M. and A.C.; writing—review and editing, A.B., A.C., I.L. and D.M.; supervision and funding acquisition, I.L., A.B. All authors have read and agreed to the published version of the manuscript.

Funding: This research was funded by Ministry of education, science and technology development Republic of Serbia, grant number OI 175073.

Institutional Review Board Statement: Not applicable.

Informed Consent Statement: Not applicable.

Data Availability Statement: All detailed information about reasons for inclusion/exclusion and quality assessment, as well as Supplementary Materials are available at https:/ / osf.io/znrwj/.

Conflicts of Interest: The authors declare no conflict of interest.

\section{References}

1. Jia, W.H.; Qin, H. De Non-viral environmental risk factors for nasopharyngeal carcinoma: A systematic review. Semin. Cancer Biol. 2012, 22, 117-126. [CrossRef] [PubMed]

2. Cancer Today. Available online: https://gco.iarc.fr/today/home (accessed on 30 June 2021). 
3. Chang, E.T.; Adami, H.O. The enigmatic epidemiology of nasopharyngeal carcinoma. Cancer Epidemiol. Biomark. Prev. 2006, 15, 1765-1777. [CrossRef]

4. Zeng, Y.-X.; Jia, W.-H. Familial nasopharyngeal carcinoma. Cancer Biol. 2002, 12, 443-450. [CrossRef] [PubMed]

5. Tsao, S.W.; Tsang, C.M.; Lo, K.W. Epstein-barr virus infection and nasopharyngeal carcinoma. Philos. Trans. R. Soc. B Biol. Sci. 2017, 372, 20160270. [CrossRef] [PubMed]

6. De Schryver, A.; Friberg, S.; Klein, G.; Henle, W.; Henle, G.; De-Thi, G.; Clifford, P.; Ho, H.C. Epstein-Barr Virus-Associated Antibody Patterns in Carcinoma of the Post-Nasal Space. Clin. Exp. Immunol. 1969, 5, 443-459. [PubMed]

7. Henle, W.; Henle, G.; Burtin, P.; Cachin, Y.; De-Schryver, A.; De-the, G.; Diehl, V.; Adams, M.; Berry, T.; Hutkin, E.; et al. Antibodies to Epstein-Barr Virus In Naso-pharyngeal Carcinoma, Other Head and Neck Neoplasms, and Control Groups. J. Natl. Cancer Inst. 1970, 44, 225-231. [PubMed]

8. Nakanishi, Y.; Wakisaka, N.; Kondo, S.; Endo, K.; Sugimoto, H.; Hatano, M.; Ueno, T.; Ishikawa, K.; Yoshizaki, T. Progression of understanding for the role of Epstein-Barr virus and management of nasopharyngeal carcinoma. Cancer Metastasis Rev. 2017, 36, 435-447. [CrossRef] [PubMed]

9. Wang, D.; Liebowitz, D.; Kieff, E. An EBV Membrane Protein Expressed in Immortalized Lymphocytes Transforms Established Rodent Cells. Cell 1985, 43, 831-840. [CrossRef]

10. Moorthy, R.K.; Thorley-Lawson, D.A. All Three Domains of the Epstein-Barr Virus-Encoded Latent Membrane Protein LMP-1 Are Required for Transformation of Rat-1 Fibroblasts. J. Virol. 1993, 67, 1638-1646. [CrossRef]

11. Kulwichit, W.; Edwards, R.H.; Davenport, E.M.; Baskar, J.F.; Godfrey, V.; Raab-Traub, N. Expression of the Epstein-Barr virus latent membrane protein 1 induces B cell lymphoma in transgenic mice. Proc. Natl. Acad. Sci. USA 1998, 95, 11963-11968. [CrossRef]

12. Da Costa, V.G.; Marques-Silva, A.C.; Moreli, M.L. The Epstein-Barr virus latent membrane protein-1 (LMP1) 30-bp deletion and XhoI-polymorphism in nasopharyngeal carcinoma: A meta-analysis of observational studies. Syst. Rev. 2015, 4, 46. [CrossRef]

13. De Oliveira, D.E.; Müller-Coan, B.G.; Pagano, J.S. Viral Carcinogenesis Beyond Malignant Transformation: EBV in the Progression of Human Cancers. Trends Microbiol. 2016, 24, 649-664. [CrossRef]

14. Coffin, W.F., III; Erickson, K.D.; Hoedt-Miller, M.; Martin, J.M. The cytoplasmic amino-terminus of the Latent Membrane Protein-1 of Epstein-Barr Virus: Relationship between transmembrane orientation and effector functions of the carboxy-terminus and transmembrane domain. Oncogene 2001, 20, 5313-5330. [CrossRef]

15. Gires, O.; Zimber-Strobl, U.; Gonnella, R.; Ueffing, M.; Marschall, G.; Zeidler, R.; Pich, D.; Hammerschmidt, W. Latent membrane protein 1 of Epstein-Barr virus mimics a constitutively active receptor molecule. EMBO J. 1997, 16, 6131-6140. [CrossRef]

16. Li, H.P.; Chang, Y.S. Epstein-Barr virus latent membrane protein 1: Structure and functions. J. Biomed. Sci. 2003, 10, 490-504. [CrossRef]

17. Miller, W.E.; Edwards, R.H.; Walling, D.M.; Raab-Traub, N. Sequence variation in the Epstein-Barr virus latent membrane protein 1. J. Gen. Virol. 1994, 75, 2729-2740. [CrossRef]

18. Edwards, R.H.; Seillier-Moiseiwitsch, F.; Raab-Traub, N. Signature Amino Acid Changes in Latent Membrane Protein 1 Distinguish Epstein-Barr Virus Strains. Virology 1999, 261, 79-95. [CrossRef]

19. Smatti, M.K.; Al-Sadeq, D.W.; Ali, N.H.; Pintus, G.; Abou-Saleh, H.; Nasrallah, G.K. Epstein-barr virus epidemiology, serology, and genetic variability of LMP-1 oncogene among healthy population: An update. Front. Oncol. 2018, 8, 211. [CrossRef]

20. Knecht, H.; Bachmann, E.; Brousset, P.; Sandvej, K.; Nadal, D.; Bachmann, F.; Odermatt, B.; Delsol, G.; Pallesen, G. Deletions within the LMP1 oncogene of Epstein-Barr virus are clustered in Hodgkin's disease and identical to those observed in nasopharyngeal carcinoma. Blood 1993, 82, 2937-2942. [CrossRef]

21. Abdel-Hamid, M.; Chen, J.J.; Constantine, N.; Massoud, M.; Raab-Traub, N. EBV Strain Variation: Geographical Distribution and Relation to Disease State. Virology 1992, 190, 168-175. [CrossRef]

22. Jeng, K.-C.G.; Hsu, C.-Y.; Liu, M.-T.; Chung, T.-T.; Liu, S.-T. Prevalence of Taiwan Variant of Epstein-Barr Virus in Throat Washings from Patients with Head and Neck Tumors in Taiwan. J. Clin. Microbiol. 1994, 32, 28-31. [CrossRef] [PubMed]

23. Chang, Y.-S.; Su, I.-J.; Chung, P.-J.; Shu, C.-H.; Ng, C.-K.; Wu, S.-J.; Liu, S.-T. Detection of an Epstein-Barr-Virus Variant in T-Cell-Lymphoma Tissues Identical to the Distinct Strain Observed in Nasopharyngeal Carcinoma in the Taiwanese Population. Int. J. Cancer 1995, 62, 673-677. [CrossRef] [PubMed]

24. Chen, H.L.; Lung, M.L.; Chan, K.H.; Griffin, B.E.; Ng, M.H. Tissue Distribution of Epstein-Barr Virus Genotypes. J. Virol. 1996, 70, 7301-7305. [CrossRef]

25. Cheung, S.T.; Lo, K.W.; Leung, S.F.; Chan, W.Y.; Choi, P.H.; Johnson, P.J.; Lee, J.C.; Huang, D.P. Prevalence of LMP1 deletion variant of Epstein-Barr virus in nasopharyngeal carcinoma and gastric tumors in Hong Kong. Int. J. Cancer 1996, 66, 711-712. [CrossRef]

26. Khanim, F.; Yao, Q.Y.; Niedobitek, G.; Sihota, S.; Rickinson, A.B.; Young, L.S. Analysis of Epstein-Barr virus gene polymorphisms in normal donors and in virus-associated tumors from different geographic locations. Blood 1996, 88, 3491-3501. [CrossRef] [PubMed]

27. Wu, S.J.; Lay, J.D.; Chen, C.L.; Chen, J.Y.; Liu, M.Y.; Su, I.J. Genomic analysis of Epstein-Barr virus in nasal and peripheral T-cell lymphoma: A comparison with nasopharyngeal carcinoma in an endemic area. J. Med. Virol. 1996, 50, 314-321. [CrossRef] 
28. Leung, S.Y.; Yuen, S.T.; Chung, L.P.; Chan, A.S.Y.; Wong, M.P. Prevalence of mutations and 30-bp deletion in the C-terminal region of Epstein-Barr virus latent membrane protein-1 oncogene in reactive lymphoid tissue and non-nasopharyngeal EBV-associated carcinomas in Hong Kong Chinese. Int. J. Cancer 1997, 72, 225-230. [CrossRef]

29. Grunewald, V.; Bonnet, M.; Boutin, S.; Yip, T.; Louzir, H.; Levrero, M.; Seigneurin, J.M.; Raphael, M.; Touitou, R.; Martel-Renoir, D.; et al. Amino-acid change in the Epstein-Barr-virus ZEBRA protein in undifferentiated nasopharyngeal carcinomas from Europe and North Africa. Int. J. Cancer 1998, 75, 497-503. [CrossRef]

30. Hahn, P.; Novikova, E.; Scherback, L.; Janik, C.; Pavlish, O.; Arkhipov, V.; Nicholls, J.; Müller-Lantzsch, N.; Gurtsevitch, V.; Grässer, F.A. The LMP1 gene isolated from Russian nasopharyngeal carcinoma has no 30-bp deletion. Int. J. Cancer 2001, 91, 815-821. [CrossRef]

31. Zhou, X.-G.; Sandvej, K.; Li, P.-J.; Ji, X.-L.; Yan, Q.-H.; Zhang, X.-P.; Da, J.-P.; Hamilton-Dutoit, S.J. Epstein-Barr virus gene polymorphisms in Chinese Hodgkin's disease cases and healthy donors: Identification of three distinct virus variants. J. Gen. Virol. 2001, 82, 1157-1167. [CrossRef]

32. Zhang, X.-S.; Song, K.-H.; Mai, H.-Q.; Jia, W.-H.; Feng, B.-J.; Xia, J.-C.; Zhang, R.-H.; Huang, L.-X.; Yu, X.-J.; Feng, Q.-S.; et al The 30-bp deletion variant: A polymorphism of latent membrane protein 1 prevalent in endemic and non-endemic areas of nasopharyngeal carcinomas in China. Cancer Lett 2002, 176, 65-73. [CrossRef]

33. Lin, S.X.; Zong, Y.S.; Wu, Q.L.; Han, A.J.; Liang, Y.J. Loss of an XhoI-site within N-terminal region of Epstein-Barr virus LMP1 gene in nasopharyngeal carcinoma. Ai Zheng 2003, 22, 1147-1151.

34. Plaza, G.; Santón, A.; Vidal, A.M.; Bellas, C. Latent membrane protein-1 oncogene deletions in nasopharyngeal carcinoma in Caucasian patients. Acta Otolaryngol. 2003, 123, 664-668. [CrossRef]

35. Tan, E.L.; Peh, S.C.; Sam, C.K. Analyses of Epstein-Barr virus latent membrane protein-1 in Malaysian nasopharyngeal carcinoma: High prevalence of 30-bp deletion, Xho1 polymorphism and evidence of dual infections. J. Med. Virol. 2003, 69, $251-257$. [CrossRef]

36. Chabay, P.; De Matteo, E.; Merediz, A.; Preciado, M.V. High frequency of Epstein Barr virus latent membrane protein-1 30 bp deletion in a series of pediatric malignancies in Argentina. Arch. Virol. 2004, 149, 1515-1526. [CrossRef]

37. Lin, J.C.; Cherng, J.M.; Lin, H.J.; Tsang, C.W.; Liu, Y.X.; Lee, S.P. Amino acid changes in functional domains of latent membrane protein 1 of Epstein-Barr virus in nasopharyngeal carcinoma of southern China and Taiwan: Prevalence of an HLA A2-restricted "epitope-loss variant". J. Gen. Virol. 2004, 85, 2023-2034. [CrossRef]

38. Nicholls, J.; Hahn, P.; Kremmer, E.; Fröhlich, T.; Arnold, G.J.; Sham, J.; Kwong, D.; Grässer, F.A. Detection of wild type and deleted latent membrane protein 1 (LMP1) of Epstein-Barr virus in clinical biopsy material. J. Virol. Methods 2004, 116, 79-88. [CrossRef]

39. Zhang, M.; Zong, Y.S.; He, J.H.; Lin, S.X.; Zhong, B.L.; Liang, Y.J. Comparison of Epstein-Barr virus infection and 30 bp-deleted LMP1 gene among four histological types of nasopharyngeal carcinoma. Chin. Med. J. 2004, 117, 608-611.

40. Dardari, R.; Khyatti, M.; Cordeiro, P.; Odda, M.; ElGueddari, B.; Hassar, M.; Menezes, J. High frequency of latent membrane protein-1 30-bp deletion variant with specific single mutations in Epstein-Barr virus-associated nasopharyngeal carcinoma in Moroccan patients. Int. J. Cancer 2006, 118, 1977-1983. [CrossRef]

41. Hadhri-Guiga, B.; Khabir, A.M.; Mokdad-Gargouri, R.; Ghorbel, A.M.; Drira, M.; Daoud, J.; Frikha, M.; Jlidi, R.; Gargouri, A. Various 30 and $69 \mathrm{bp}$ deletion variants of the Epstein-Barr virus LMP1 may arise by homologous recombination in nasopharyngeal carcinoma of Tunisian patients. Virus Res. 2006, 115, 24-30. [CrossRef]

42. See, H.; Yap, Y.; Yip, W.; Seow, H. Epstein-Barr virus latent membrane protein-1 (LMP-1) 30-bp deletion and Xho I-loss is associated with type III nasopharyngeal carcinoma in Malaysia. World J. Surg. Oncol. 2008, 6, 18. [CrossRef]

43. Tiwawech, D.; Srivatanakul, P.; Karalak, A.; Ishida, T. Association between EBNA2 and LMP1 subtypes of Epstein-Barr virus and nasopharyngeal carcinoma in Thais. J. Clin. Virol. 2008, 42, 1-6. [CrossRef] [PubMed]

44. Li, D.J.; Bei, J.X.; Mai, S.J.; Xu, J.F.; Chen, L.Z.; Zhang, R.H.; Yu, X.J.; Hong, M.H.; Zeng, Y.X.; Kang, T. The dominance of China 1 in the spectrum of Epstein-Barr virus strains from cantonese patients with nasopharyngeal carcinoma. J. Med. Virol. 2009, 81, 1253-1260. [CrossRef] [PubMed]

45. Banko, A.; Lazarevic, I.; Cupic, M.; Stevanovic, G.; Boricic, I.; Jovanovic, T. Carboxy-terminal sequence variation of LMP1 gene in Epstein-Barr-virus-associated mononucleosis and tumors from Serbian patients. J. Med. Virol. 2012, 84, 632-642. [CrossRef]

46. Gurtsevitch, V.E.; Iakovleva, L.S.; Shcherbak, L.N.; Goncharova, E.V.; Smirnova, K.V.; Diduk, S.V.; Kondratova, V.N.; Maksimovich, D.M.; Lichtenstein, A.V.; Seniuta, N.B. The LMP1 oncogene sequence variations in patients with oral tumours associated or not associated with the Epstein Barr. Mol. Biol. 2013, 47, 987-995. [CrossRef]

47. Senyuta, N.; Yakovleva, L.; Goncharova, E.; Scherback, L.; Diduk, S.; Smirnova, K.; Maksimovich, D.; Gurtsevitch, V. Epstein-barr virus latent membrane protein 1 polymorphism in nasopharyngeal carcinoma and other oral cavity tumors in Russia. J. Med. Virol. 2014, 86, 290-300. [CrossRef] [PubMed]

48. Neves, M.; Marinho-Dias, J.; Ribeiro, J.; Esteves, M.; Maltez, E.; Baldaque, I.; Breda, E.; Monteiro, E.; Medeiros, R.; Sousa, H. Characterization of Epstein-Barr virus strains and LMP1-deletion variants in Portugal. J. Med. Virol. 2015, 87, 1382-1388. [CrossRef]

49. Niya, M.H.K.; Tameshkel, F.S.; Keyvani, H.; Esghaei, M.; Panahi, M.; Zamani, F.; Tabibzadeh, A. Epstein-Barr virus molecular epidemiology and variants identification in head and neck squamous cell carcinoma. Eur. J. Cancer Prev. 2020, $29,523-530$. [CrossRef] 
50. Tham, T.; Machado, R.; Russo, D.P.; Herman, S.W.; Teegala, S.; Costantino, P. Viral markers in nasopharyngeal carcinoma: A systematic review and meta-analysis on the detection of p16INK4a, human papillomavirus (HPV), and Ebstein-Barr virus (EBV). Am. J. Otolaryngol. Head Neck Med. Surg. 2021, 42, 102762. [CrossRef]

51. Katabi, N.; Lewis, J.S. Update from the 4th Edition of the World Health Organization Classification of Head and Neck Tumours: What Is New in the 2017 WHO Blue Book for Tumors and Tumor-Like Lesions of the Neck and Lymph Nodes. Head Neck Pathol. 2017, 11, 48-54. [CrossRef]

52. Robinson, M.; Suh, Y.-E.; Paleri, V.; Devlin, D.; Ayaz, B.; Pertl, L.; Thavaraj, S. Oncogenic human papillomavirus-associated nasopharyngeal carcinoma: An observational study of correlation with ethnicity, histological subtype and outcome in a UK population. Infect. Agent Cancer 2013, 8, 30. [CrossRef]

53. Verma, N.; Patel, S.; Osborn, V.; McBride, S.; Riaz, N.; Lee, A.; Katabi, N.; Sherman, E.; Lee, N.Y.; Tsai, C.J. Prognostic significance of human papillomavirus and Epstein-Bar virus in nasopharyngeal carcinoma. Head Neck 2020, 42, 2364-2374. [CrossRef]

54. Shannon-Lowe, C.; Rickinson, A. The Global Landscape of EBV-Associated Tumors. Front. Oncol. 2019, 9, 713. [CrossRef]

55. Pathmanathan, R.; Prasad, U.; Sadler, R.; Flynn, K.; Raab-Traub, N. Clonal proliferations of cells infected with Epstein-Barr virus in preinvasive lesions related to nasopharyngeal carcinoma. N. Engl. J. Med. 1995, 333, 693-698. [CrossRef]

56. Perez-Ordoñez, B. An Update on Epstein-Barr Virus and Nasopharyngeal Carcinogenesis. Head Neck Pathol. 2007, 1, 141-145. [CrossRef]

57. Tsang, C.M.; Yip, Y.L.; Lo, K.W.; Deng, W.; To, K.F.; Hau, P.M.; Lau, V.M.Y.; Takada, K.; Lui, V.W.Y.; Lung, M.L.; et al. Cyclin D1 overexpression supports stable EBV infection in nasopharyngeal epithelial cells. Proc. Natl. Acad. Sci. USA. 2012, 109, E3473-E3482. [CrossRef]

58. Hu, L.-F.; Zabarovsky, E.R.; Chen, F.; Cao, S.L.; Ernberg, I.K.; Winberg, G. Isolation and sequencing of the Epstein-Barr virus BNLF-1 gene (LMP1) from a Chinese nasopharyngeal carcinoma. J. Gen. Virol. 1991, 72, 2399-2409. [CrossRef]

59. Banko, A.V.; Lazarevic, I.B.; Folic, M.M.; Djukic, V.B.; Cirkovic, A.M.; Karalic, D.Z.; Cupic, M.D.; Jovanovic, T.P. Characterization of the variability of Epstein-Barr virus genes in nasopharyngeal biopsies: Potential predictors for carcinoma progression. PLoS ONE 2016, 11, e0153498. [CrossRef]

60. Dawson, C.W.; Eliopoulos, A.G.; Blake, S.M.; Barker, R.; Young, L.S. Identification of functional differences between prototype Epstein-Barr virus-encoded LMP1 and a nasopharyngeal carcinoma-derived LMP1 in human epithelial cells. Virology 2000, 272, 204-217. [CrossRef]

61. Edwards, R.H.; Sitki-Green, D.; Moore, D.T.; Raab-Traub, N. Potential Selection of LMP1 Variants in Nasopharyngeal Carcinoma. J. Virol. 2004, 78, 868-881. [CrossRef]

62. Kanda, T.; Yajima, M.; Ikuta, K. Epstein-Barr virus strain variation and cancer. Cancer Sci. 2019, 110, 1132-1139. [CrossRef] [PubMed]

63. Kwok, H.; Chiang, A.K.S. From conventional to next generation sequencing of Epstein-Barr virus genomes. Viruses 2016, 8, 60. [CrossRef] [PubMed]

64. Liberati, A.; Altman, D.G.; Tetzlaff, J.; Mulrow, C.; Gøtzsche, P.C.; Ioannidis, J.P.A.; Clarke, M.; Devereaux, P.J.; Kleijnen, J.; Moher, D. The PRISMA statement for reporting systematic reviews and meta-analyses of studies that evaluate health care interventions: Explanation and elaboration. PLoS Med. 2009, 6, e1000100. [CrossRef] [PubMed]

65. Stroup, D.F.; Berlin, J.A.; Morton, S.C.; Olkin, I.; Williamson, G.D.; Rennie, D.; Moher, D.; Becker, B.J.; Sipe, T.A.; Thacker, S.B. Meta-analysis of Observational Studies in Epidemiology A Proposal for Reporting B ECAUSE OF PRESSURE FOR TIMELY. JAMA 2000, 283, 2008-2012. [CrossRef] [PubMed]

66. Wells, G.; Shea, B.; Robertson, J.; Peterson, J.; Welch, V.; Losos, M.; Tugwell, P. The Newcastle-Ottawa Scale (NOS) for Assessing the Quality of Nonrandomized Studies in Meta-Analysis. Eur. J. Epidemiol. 2010, 25, 603-605.

67. Cumpston, M.; Li, T.; Page, M.J.; Chandler, J.; Welch, V.A.; Higgins, J.P.; Thomas, J. Updated guidance for trusted systematic reviews: A new edition of the Cochrane Handbook for Systematic Reviews of Interventions. Cochrane Database Syst. Rev. 2019, 10, ED000142. [CrossRef] [PubMed]

68. RevMan /Cochrane Training. Available online: https://training.cochrane.org/online-learning/core-software-cochrane-reviews/ revman (accessed on 29 June 2021). 